\title{
'IT IS ALL SO STRANGELY INTERTWINED': A DISCUSSION BETWEEN HANS BENDER AND CARL GUSTAV JUNG ABOUT SYNCHRONICITY (1960)
}

UWE SCHELLINGER, ANDREAS ANTON, MARC WITTMANN

PHANÊS • VOLUME $4 \cdot 2021 \bullet$ PP. 1-50

https://doi.org/10.32724/phanes.2021.schellinger.et.al 


\begin{abstract}
Hans Bender, German parapsychologist and professor at the Freiburg University, met with C. G. Jung on December 8, 1960. The discussion was recorded, and the transcribed version is available here for the first time in English. A key aspect of our article is a description of the phenomenon of synchronicity based on Hans Bender's concrete experiences during a drive through Switzerland to an Eranos Conference in Ascona and further on to the Côte d'Azur for a workshop of the Parapsychology Foundation in August 1960. At the same time, his mother suffered a stroke, which caused her death shortly afterward. Bender was returning to Freiburg at the time when she died. He was familiar with the stages of his return trip from earlier trips. He had intensely emotional experiences at certain places, which he, in retrospect, interpreted as synchronisticin connection with hismother's death.
\end{abstract}

\title{
KEYWORDS
}

C.G. Jung, Hans Bender, Synchronicity, Psi experiences. 
$\mathrm{n}$ December 8, 1960, Hans Bender, then 53 years
old and Germany's most famous representative of
parapsychology, visited the aged founder of analytical
psychology, Carl Gustav Jung, in Küsnacht near Zürich. The reason for and background of the conversation between Bender and Jung was the death of Bender's mother, Alice Bender-Hartlaub, who had suddenly died of a stroke on August 24, 1960, in Freiburg in Breisgau. ${ }^{1}$

His mother's death made Bender aware of various paranormal, above all synchronistic, phenomena which he had experienced and wanted to discuss with the famous Swiss psychologist. These phenomena, which he had personally experienced and in his family history, were especially meaningful to Hans Bender. Many years later, he declared looking back that he had had 'most profound Psi experiences on the occasion of his mother's unexpected death'. The conversation with Jung, whom Bender had considered an exceptional scientific authority for years, remained 'unforgettable' for the parapsychologist from Freiburg (Bender and Mischo 1983:24). The conversation between Bender and Jung on December 8, 1960, was recorded on tape, which is deposited in the Archives of the Institute for Frontier Areas of Psychology and Mental Health in Freiburg, Germany (Institut für Grenzgebiete der Psychologie und Psychohygiene, $[I G P P]) .{ }^{2}$ The main topic of the scientific conversation was the principle of synchronicity, so-called meaningful coincidences. The entire process and exact wording of the conversation has been published for the first time after nearly six decades in the original German in 2019 (Schellinger \& al 2019). Here we present an English translation of the article with several editorial changes.

\footnotetext{
${ }^{1}$ This is the English-language as well as revised version of a German article which was previously published in the journal Zeitschrift für Anomalistik by Schellinger, Wittmann, and Anton (2019). We thank the Gesellschaft für Anomalistik e.V. (Society for Anomalistics) and in particular Gerhard Mayer for the permission to translate and publish this article. We thank Barbara Herzberger for the translation and Christian Roesler for further literature references. We are grateful to Janne Bender, the daughter of Hans Bender, for providing us with additional personal information (3.3.2020).

${ }^{2}$ Archive of the Institute for Frontier Areas of Psychology and Mental Health (Institut für Grenzgebiete der Psychologie und Psychohygiene [IGPP Archive]), 4/2-370. Compare the circumstances of the tape recording in Gruber's report (1993:214).
} 


\section{THE VISITOR, HANS BENDER (1907-1991)}

Hans Bender is considered the most important and best-known German parapsychologist in the second half of the 20th century. He was born on February 5, 1907, in Freiburg in Breisgau as the son of the attorney Eric Bender and his wife Alice, nee Hartlaub (born in Bremen). After completing school, Bender first studied law in Lausanne and Paris and then, from 1927, psychology, philosophy, and romance studies in Freiburg, Heidelberg, Berlin, and Bonn. In 1933, he received his Doctorate in Bonn with a parapsychologically-oriented thesis on 'Psychic Automatisms: The Experimental Psychology of Subconscious Extrasensory Perception' (Zur Experimentalpsychologie des Unterbewussten und der außersinnlichen Wahrnehmung). Then he worked for several years as scientific assistant at the Psychological Institute of the Bonn University. During this time, Bender also conducted medical studies which he completed in 1939. In June 1940, he married Henriette Wichert, with whom he had been collaborating on scientific experiments concerning clairvoyance and telepathy in Bonn since 1932. Bender received his post-doctorate (habilitation) in 1941 with a thesis on 'Experimental Visions. A Contribution to the Problem of Sensory Misperception of the Consciousness of Reality and the Levels of Personality' (Experimentelle Visionen. Ein Beitrag zum Problem der Sinnestäuschung des Realitätsbewußtseins und der Schichten der Persönlichkeit).

In 1941 Bender was offered an appointment as lecturer at the newlyopened Reich University in Strasburg. There Bender headed the Institute for Psychology and Clinical Psychology from 1941 to 1944. Late in 1942 he established an Institute of Frontier Science (also known as 'Paracelsus Institute'), at which he employed the well-known astrologist, Thomas Ring (1892-1983), among others. In July, 1941, Bender was appointed extraordinary professor. He spent several months as a prisoner of war at the end of the war, but was able to return to his home town in Freiburg relatively early, in August 1945. There he founded the Study Group for Frontier Areas in Psychology with which he prepared for the foundation of the Institute for Frontier Areas of Psychology and Mental Health (IGPP). This extramural institute was opened in a new building above the city on June 19, 1950. Bender was able to re-establish himself in the Albert-Ludwig University

${ }^{3}$ Despite Hans Bender's central importance for the scientific history of parapsychology, there is no complete biographic description of his life and works. See Gruber's merely popular scientific monography (1993). For an overview, see: Bauer (2015), Miller (2010) und Resch (1991). For various aspects of Bender's scientific biography, see Bauer (1998), Hausmann (2006), Hausmann (2005/2006/2007); Hausmann (2013); Kaltenbrunn (2015); Lux (2013); Lux (2015), and Moragiannis (2003). 
in Freiburg. In 1946 he took over an interim professorship at the Institute of Psychology. He was appointed Professor Extraordinarius for Frontier Areas in Psychology in 1954. Bender regularly offered lectures on topics from the field of parapsychology and frontier areas of psychology. In 1967 Bender's field was reorganised into a Chair for Psychology and Frontier Areas in Psychology. He was then both Chair at the Freiburg University and Director of the IGPP until his retirement in 1975. Bender established his position as the main representative of parapsychology in Germany through numerous lectures, publications, and further scientific activities in the second half of the 20th century. The Journal for Parapsychology and Frontier Areas of Psychology (Zeitschrift für Parapsychologie und Grenzgebiete der Psychologie) has been an important publication since 1957. Bender's extraordinary and controversial research area, as well as his remarkable field of operation, gradually resulted in, aside from his scientific reputation, his considerable public effectiveness, above all during the 1970s. From 1975 to 1991 he continued directing the Institute for Frontier Areas of Psychology and Mental Health, which he had founded. Hans Bender died on May 7, 1991 in Freiburg in Breisgau.

\section{CARL GUSTAV JUNG (1875-1961) AND THE PRINCIPLE OF SYNCHRONICITY}

From the very beginning of his medical studies in Basel, Carl Gustav Jung was interested in spiritualistic and parapsychological phenomena, like visitations and so-called Poltergeists, and reported on his own experiences at that time. Working under Eugen Bleuler at the Psychiatric University Clinic Burghölzli in Zürich since 1900, he submitted his doctoral thesis 'On the Psychology and Pathology of so-called Occult Phenomena' (Zur Psychologie und Pathologie sogenannter occulter Phänomene) in 1902. Parapsychological topics were a focus of his psychiatric and later depthpsychological studies. During his working life, he was also intensely involved in topics like alchemy, the Chinese oracle I Ching, UFO sightings, and astrology, which were hardly to not-at-all recognised in science.

The principle of synchronicity which he discussed with Bender is one of Jung's most important concepts and is still being extensively 
discussed by scholars (Roesler 2014, 2018, Roesler and Giebeler 2015). The term was increasingly used by Jung since the end of the 1940s (Jung 1951, Jung 1952, Jaffé 1960). Jung apparently used the term 'synchronistic principle' for the first time during a commemorative lecture for the I Ching translator and interpreter Richard Wilhelm (1873-1930), in May 1930 (Miller 2009, cp. also Gieser 2005:277). Jung described 'synchronicity' as the simultaneous occurrence of inner experiences with an external event. This parallel, synchronous appearance of external events with the momentary subjective condition is experienced as meaningful and its content is directly connected with these events (Jung 1952a, Jung 1952b, Yiassemides 2014). It is important to note that the internal and the external event have no causal connection. Jung assumed that the personal, time-dependent psychic condition and the archetypical, timeless realm become united during synchronistic events. In this way, the emotionally-experienced condition can gain individual meaning. An event will then be referred to as synchronistic if the experience has a personal meaning for the person who experienced it. Beginning in the 1930s, Jung exchanged letters exploring explanatory models of the synchronicity principle with the physicist and later Nobel Prize winner Wolfgang Pauli (Miller 2009). The Jung-Pauli dialogue tried, among other things, to integrate quantum-theoretical concepts, like complementarity in order to unify the two concepts, causality and synchronicity, as complementary characteristics of attempts to understand the world (Atmanspacher and Fuchs 2014, Gieser 2005, Miller 2009). Scientific models of an expanded or generalised quantum theory which attempt to integrate this principle into experimental psychology (Atmanspacher \& al 2010) and parapsychology (Lucadou \& al 2007) still exist. 


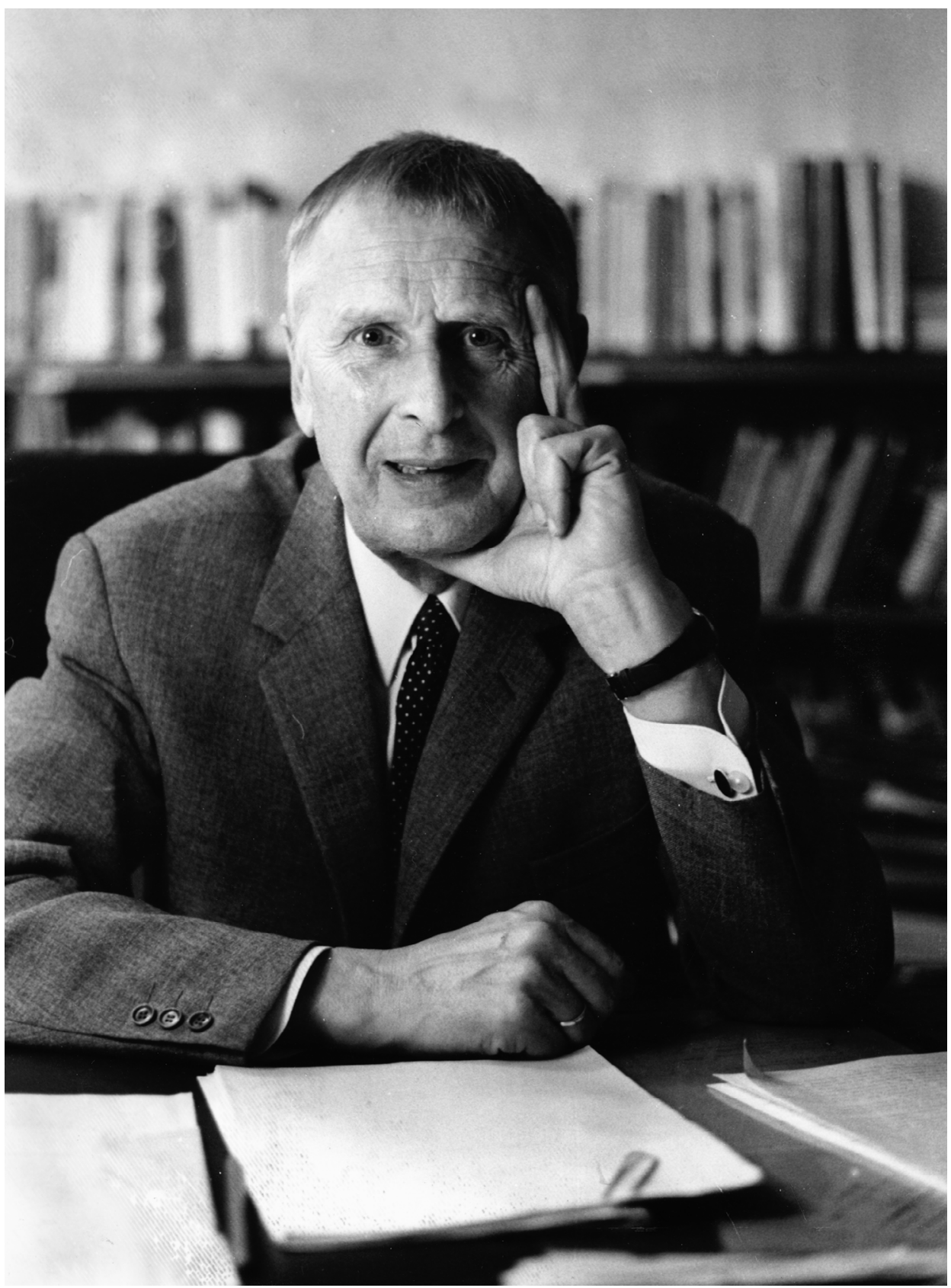

Fig. 1: Hans Bender (1907-1991), ca. 1960 (IGPP Archive) 


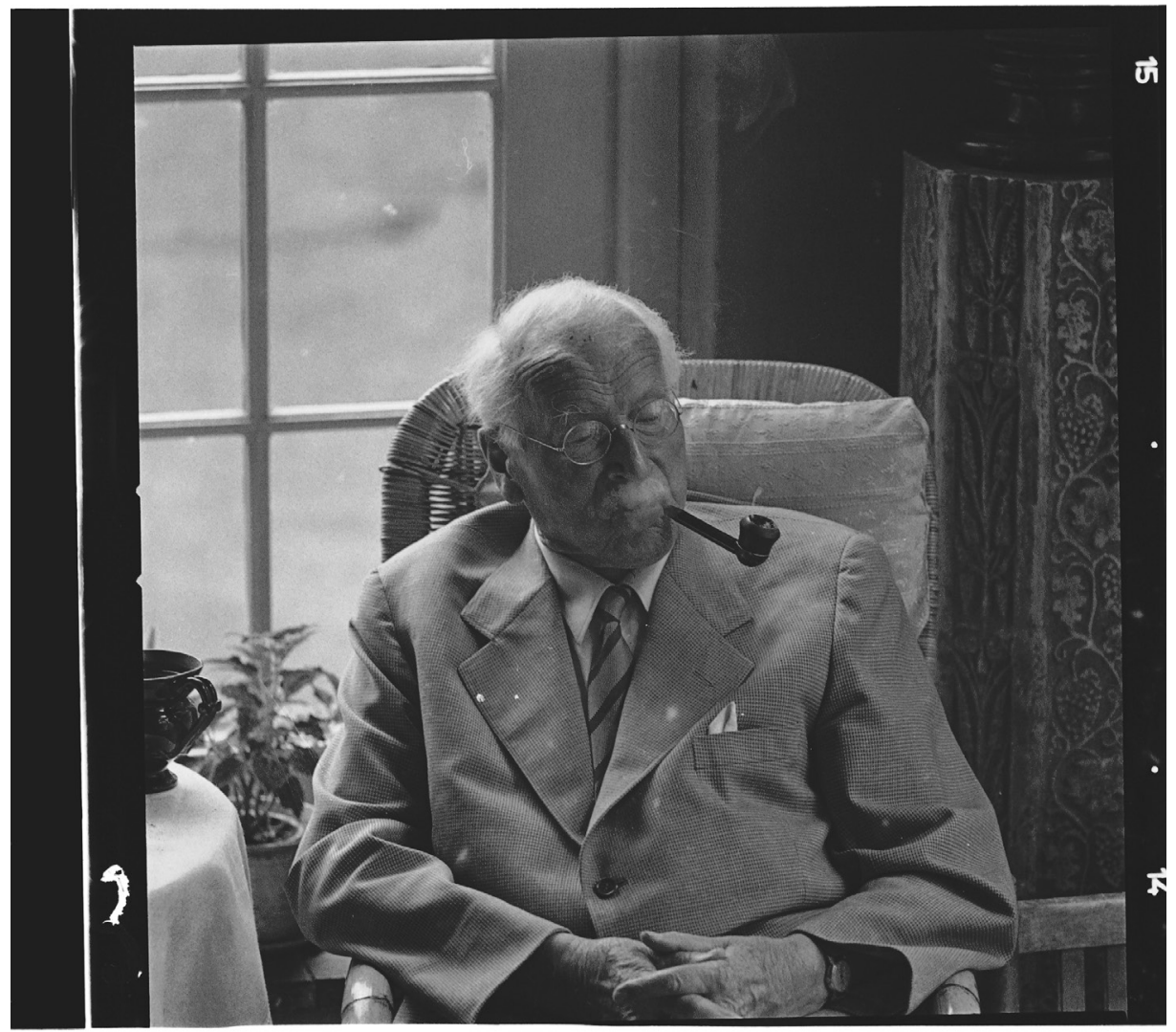

Fig. 2: Carl Gustav Jung (1875-1961) in later years (C. G. Jung Institute, Zürich; Foto: Mönstedt)

\section{ADMIRATION AND DISTANCE: HANS BENDER AND CARL GUSTAV JUNG BETWEEN 1932 AND 1956}

Hans Bender and Carl Gustav Jung were in contact from the middle of 1932. On August 27, 1932, Bender, then a doctoral candidate at Bonn University, sent Jung a letter and two-part report of a dream his former test subject and later wife, Henriette Wichert, had had on August 12, 1932. The report contained a description of the structure of a telepathy experiment Bender had designed, along with a five-page protocol of results with four test subjects performed on August 12 and 14, 1932. Bender emphasised how instructive Jung's dissertation, 'The Psychology and Pathology of so-called Occult Phenomena', had been (Jung 1902). In general, he wrote, Jung's collected works were of 'decisive importance' to him. For this reason, Bender 'very immodestly' requested a prompt 
interview with his famous colleague in Zürich to better elucidate his parapsychological experiments. ${ }^{4}$ This visit, however, did not take place (Gruber 1993:49f). The two first met one another at the beginning of February 1933, when Jung witnessed a telepathy experiment of the doctoral candidate Bender during a visit to Bonn University (Gruber 1993: 50-53, IGPP Archive 10/5-23: Letter 30.1.1933 Jung to Bender).

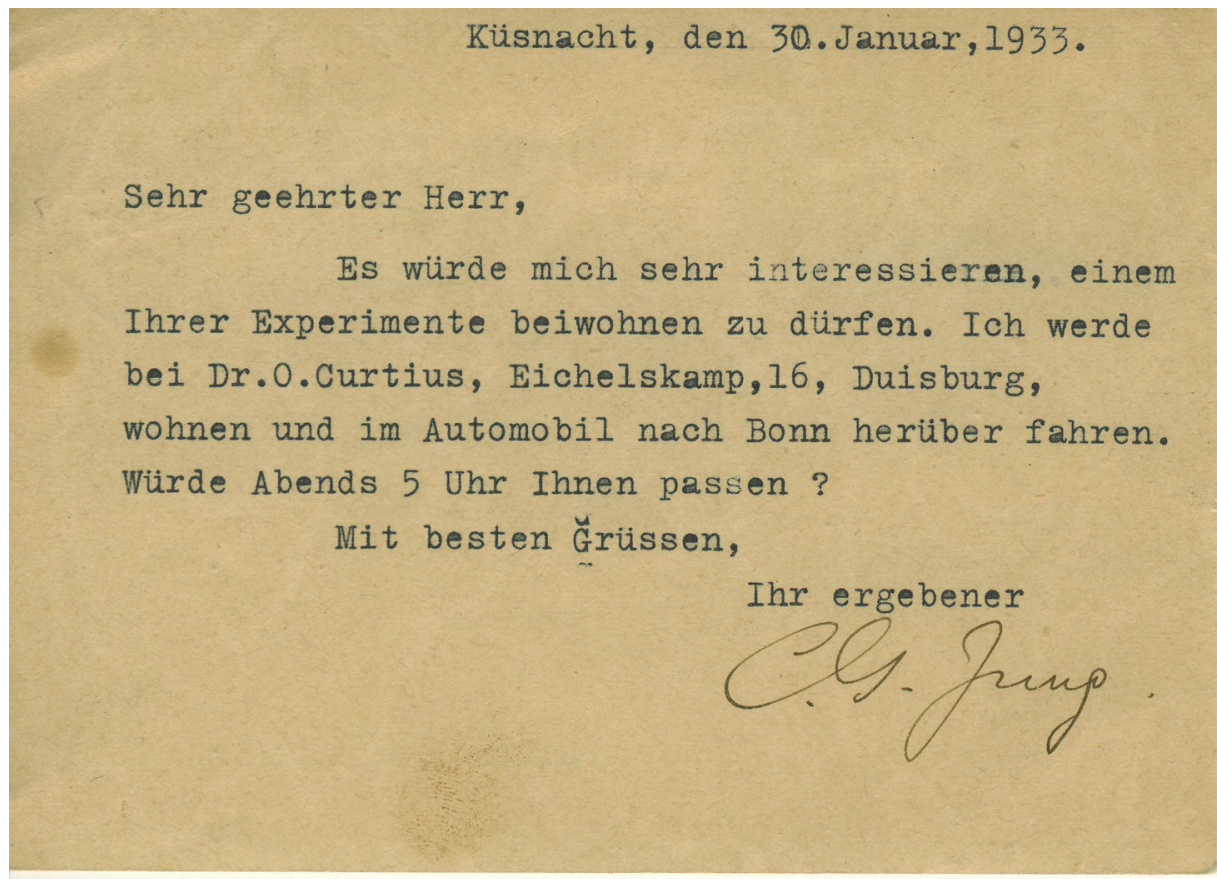

Fig. 3: Postcard from Jung to Bender on January 30, 1933 (IGPP Archive)

On this occasion, Jung encouraged the young scientist to contact him personally. During the following years, Bender repeatedly turned to him for advice. He wanted to send Jung a further protocol about 'telepathic apparitions' which had appeared in the context of his telepathy experiments and 'all were related to very personal things' in May 1934. Bender again requested an appointment with Jung to discuss these phenomena. We were not able to ascertain whether Bender realised this intention or whether a meeting in Küsnacht took place at this time (IGPP Archive 10/5-23: Letter 30.1.1933 Jung to Bender). In October 1935, Bender contacted Jung's

${ }^{4}$ ETH Library Zürich, University Archive, Hs 1056: 12275: Hans Bender to Carl Gustav Jung (27.8.1932). A total of 94 texts from 1932 to 1961, which document the contact between Bender and Jung, can be found in the University Archives of the ETH Zürich. A few of them are still inaccessible. We are grateful to Thomas Fischer (C.G. Jung Foundation, Zürich) und Claudia Briellmann (ETH Zürich) for their information. 
secretariat and sent a new dream report (ETH Library Zürich, ETHZ, University Archive, Hs 1056:12274). Due to the continuing strained relationship between Bender and his girlfriend, Henriette, resulting from the telepathic contacts between them and their dream experiences, Gruber reports that Bender, in his unhappy mood, again turned to Jung on March 7, 1936, 'What cure exists for this witchcraft? [...] I fear I was not sufficiently armed for the phantoms I summoned' (Gruber 1993:65). Bender visited Jung in Küsnacht near Zürich for probably the first time shortly thereafter (Gruber 1993:65f, Archives de l'occupation française en Allemagne et en Autriche Colmar, Bade 4103: Bender, Hans). Jung represented an important dialogue partner, not only with regards to scientific, but also private matters. The young psychologist from Freiburg repeatedly sought personal and direct contact with the famous Swiss psychiatrist. We were not able to find any written correspondence between Bender and Jung between 1937 and 1950. One can, however, assume that the link between the two was never completely severed, not even during the years of the National Socialist dictatorship and the Second World War. ${ }^{5}$

Bender stated that the two had met again at a party in Basel celebrating Jung's 75th birthday in 1950, possibly for the first time since the war. Available correspondence between Bender and Jung resumes with a letter written on November 13, 1950. Hans Bender, who had since become a famous parapsychologist, reaffirmed his gratitude to the well-known psychiatrist: 'Since my first experiments in Bonn in 1932, which youattended once, I always found the very best support for the struggle to implement this research into academia in your works' (ETHZ, UA, Hs 1056:16618).

During the following years, Bender continually attempted to intensify both the scientific exchange and direct contact with Jung. At different times he requested a personal meeting, but without the desired result (ETHZ, UA, Hs 1056:16618, 170857, 17838). He also experienced greater disappointments. In the spring of 1951, he invited Jung to a planned conference about 'The Problem of Synchronicity' to take place in mid-May at the IGPP in Freiburg (ETHZ, UA, Hs 1056:17461). This conference, originally dated before the Eranos Conference of August 1951, indicates Bender's early interest in synchronicity. After the planning was already well advanced, and after preliminary talks had been conducted, and numerous participants had registered - in part

\footnotetext{
${ }^{5}$ The correspondence between Bender and Jung is strikingly incomplete both in the historical sources in the IGPP Archive and in the university archive of the ETH in Zürich. Numerous letters have disappeared for unknown reasons or must be considered lost.
} 
because of Jung's announced appearance (ETHZ, UA, Hs 1056:17840, 17463) - Jung cancelled his participation for reasons of health a month before the conference was to take place (ETHZ, UA, Hs 1056:17841).

In the following years, Hans Bender adhered steadfastly to Jung as a scientific authority. He repeatedly indicated how immense Jung's influence on his field of endeavour was: 'Your works have contributed a decisive stimulation to parapsychological research.' (ETHZ, UA, Hs 1056:17465). However, their meetings remained sporadic. It proved difficult for Bender, aside from written communication, to get personal appointments with the highly-demanded Jung. Bender's arranged appointments with Jung and personal discussions in Küsnacht are documented on March 7, 1951 (ETHZ, UA, Hs 1056:17839), possibly in 1953 (ETHZ, UA, Hs 1056:20048), and finally on May 16, 1954 (ETHZ, UA, Hs 1056:20537, 20049). Conversely, Jung never visited the IGPP in Freiburg. This conveys the impression of a lopsided relationship with conflicting expectations. While Hans Bender continually attempted to strengthen the contact with the world-famous expert in analytical psychology, to integrate him into his (Bender's) scientific projects, and rarely spared his expressions of admiration for Jung to achieve this purpose, Jung preferred to maintain a polite, professional distance to his young colleague and made it obvious that it was he who determined the direction in their relationship.

\section{SYNCHRONISTIC PHENOMENA, ASTROLOGY, UND UFOS: HANS BENDER AND CARL GUSTAV JUNG BETWEEN 1957 AND 1961}

Towards the end of the 1950s, Bender and Jung maintained a comprehensive professional correspondence in which they, among other things, intensively exchanged different questions in connection with synchronistic phenomena (IGPP Archive E/21: Correspondence JungBender 1958, 1961; ETHZ, UA, Hs 1056). In August 1951, Bender heard an instructive lecture by Jung titled 'About Synchronicity' at the Eranos Convention in Ascona (published as 'Über Synchronizität', Jung 1952a) which apparently had an enduring effect on him and led him to reflect on the relationship between synchronistic phenomena and psychic phenomena.

The concrete occasion for the intensified written exchange in $1957 / 1958$ was the publication of an article on an astrological study by Jung in the Journal for Parapsychology and Frontier Areas of Psychology (Zeitschrift für Parapsychologie und Grenzgebiete der Psychologie $[Z f P])$, edited by Bender. Between September 1957 and spring 1958, 
Bender and Jung corresponded concerning a text by Jung (at that time unpublished in German), on methodological questions about astrological statistics, which Jung wanted to place in Bender's journal (ETHZ, UA, Hs 1056:24489, 23789). This text was taken from an earlier work about synchronicity in English (Jung and Pauli 1955) and also referred to Jung's longer article 'Synchronicity as a Principle of Causal Relationships' (Synchronizität als ein Prinzip kausaler Zusammenhänge) in 1952 (Jung 1952b). Jung had compared the horoscopes of married individuals and examined whether there existed a statistical cluster of certain aspects, as was to be expected according to traditional astrological teachings. He did not seek to find evidence for or against astrology, but to find out whether and how statistical distributions arrange themselves within an astrological context which, according to Jung, exhibits a core archetypical character. Jung interpreted the statistically significant, but inhomogeneous correlations of parts of his examinations as synchronistic phenomena (Jung 1957/58). Jung often emphasised to Bender that both synchronistic phenomena and causal mechanisms must be taken into consideration in astrology: 'As I said, astrology seems to require different hypotheses, and I am unable to declare myself for the one or the other. We will have to take refuge in a mixed declaration because nature does not tend to the housekeeping of intellectual concept formation.' (IGPP Archive E/21: Letter 10.4.1958 Jung to Bender in Correspondence with Jung 1958-1961).

Bender composed an introduction for Jung's article for the ZfP which he sent to Jung on February 9, 1958, for review. He mentioned a 'sought synchronistic effect' in relation to Jung's astrology experiment (ETHZ, UA, 1056:25184). This displeased Jung, which he made clear in his letter to Bender on February 12, 1958: 'Your introduction about synchronicity is absolutely appropriate up to the place where you speak of "sought synchronistic effect". This effect was, if I may allow myself to say so, actually not sought, but found, and that probably because the experiment was so conceived with as little limitation as possible, i.e., in other words, coincidence was allowed considerable leeway. If you allow the "synchronistic arrangement" as little possible latitude as possible, coincidence will obviously be restricted and the synchronistic "effect" impeded' (Jung 1957/1958:82f, Jung 1973:157-159, IGPP Archive E/21: Letter 12.2.1958 Jung to Bender).

Bender therefore changed his preliminary remark. The 'experimenter's routine' misled him to use this wording. He crossed out 'synchronistic effect' and wrote instead, 'This is the synchronistic phenomenon' (Bender 1957/1958:81). Bender requested Jung to allow 
him to print his explanatory letter from February 12, 1958, in front of the article in the ZfP. Bender suggested always putting the term 'effect', which appeared several times in Jung's letter, in quotation marks since he did not agree with Jung's opinion of a (at least partially) non-causal explanatory relationship in astrology. Here again, Bender insistently explained to Jung that the 'problem of synchronicity' was exceptionally important to him (ETHZ, UA, Hs 1056:25185). In May, 1958, the issue of the ZfP with Jung's article, Jung's letter from February 12, 1958, and Bender's 'preliminary remarks' finally appeared (Jung 1957/1958). In the meantime, C.G. Jung had written Bender two further letters in which he elaborately presented his views concerning synchronicity (Jung 1973, 159164; IGPP Archive E/21: Letters 6.3.1958 and 10.4.1958 Jung to Bender).

In their further correspondence, Bender and Jung also discussed UFOs. The occasion for this was the book Jung published in 1958 titled 'Flying Saucers: A Modern Myth of Things Seen in the Skies' (Ein moderner Mythus. Von Dingen, die am Himmel gesehen werden) in which Jung attempted to interpret UFO phenomena in terms of depth psychology (Jung 1958). Jung did not categorically rule out that at least some UFO sightings could be based on actual, objective phenomena, which might even be of extraterrestrial origin, but emphasised that UFO phenomena are essentially to be understood as psychological. According to Jung, UFO phenomena are primarily manifestations of unconscious psychic processes, projections of human anxieties, longings, and desires, as well as the activation of a central archetype ('the self'). On April 5, 1958, Bender wrote Jung that he had read the book with the 'greatest interest' and admiration for the author's 'inexhaustible productivity' and sent Jung transcriptions of interviews recorded on tape with numerous witnesses who maintained they had seen UFOs to clarify the 'question of the objectivity of the alleged celestial phenomena' (ETHZ, UA, Hs 1056:25188). Jung considered these cases to confirm his opinion of UFO phenomena and stressed that UFO sightings could also arise in the form of collective visions, which ultimately cannot be differentiated from actual phenomena: 'Empirically such visions are just like realities, and there is no applicable criterion to ever perceive them as unreal.' (IGPP Archive E/21: Letter 12.4.1958 Jung to Bender). At the end of his book on UFOs, Jung wrote: 'Since they seem to have appeared more frequently after the Second World War than before, it may be that they are synchronistic phenomena or "meaningful coincidences". The psychic situation of mankind and the UFO phenomenon as a physical reality bear no recognizable causal relationship to one another, but they seem 
to coincide in a meaningful manner. The meaningful connection is the product on the one hand of projection and on the other of round and cylindrical forms which embody the projected meaning and have always symbolized the union of the opposites' (Jung 1958:143-144; English translation: Jung 1979:111). In various publications, Bender seized upon Jung's concept that UFO phenomena are to be interpreted as the expression of synchronistic phenomena, compared UFO sightings with paranormal appearances, and also referred to them as 'hauntings in the sky' (Bender 1959:41, ETHZ, UA, Hs 1056:26727, 30404). This comparison seemed likely because, analogous to Bender's parapsychological interpretation of paranormal phenomena as manifestations of inner-psychic processes, Jung's approach ascribed UFO phenomena to synchronistic connections between collective human mood states and the celestial phenomena reported by the UFO witnesses. Regarding these UFO phenomena, Bender stated that 'a psychological motive, an emotional tension whose origin lay in the collective plight, in the threatening current world situation [was responsible]. Just as in the times of crisis of earlier centuries, in apocalyptic moods, signs in the sky are seen' (Bender 1959:45).

Early in 1960, Bender and Jung again picked up the topic of synchronicity in their correspondence. In February 1960 Jung sent Bender via his colleague, Aniela Jaffé, his English 'correspondence [...] concerning questions of synchronicity' with the British parapsychologist, Anthony Donald (Tony) Cornell (1924-2010) together with the request that Bender evaluate these texts (ETHZ, UA, Hs 1056: 28617). Jung had come to trust Bender's expert opinion of synchronicity. Bender assured Jung that he would translate these letters and publish them in the ZfP in the foreseeable future (ETHZ, UA, Hs 1056: 27920). Jaffé and Bender repeatedly compared notes about Jung's long written reply to Cornell on synchronicity during the following months until June, 1960. Professor Jung later expressed the wish that, when the letter was published, 'the name of the addressee not be mentioned.' (ETHZ, UA, Hs 1056: 28621).

Jung's assistant, Aniela Jaffé, increasingly became Bender's contact person during these months, while Jung, now well advanced in years, was extremely hard to reach. Nevertheless, Bender sent his 'sincerest congratulations' on the occasion of Jung's 85th birthday in July, 1960, and acknowledged him in an extensive editorial in the ZfP (Bender 1960).

Hans Bender was occupied with questions concerning synchronicity during the entire 1950s and again, in 1960, for reasons that will become evident. The remarkable coincidences which he experienced in connection with his mother's death in August 1960 seems to have had a huge effect 
on him. He decided to discuss these with C. G. Jung as soon as possible. However, he had lost direct contact with him since spring 1958, since all communication had only been conducted via Aniela Jaffé for months. During a visit to her in Küsnacht in mid-September, 1960, Bender had sounded out whether Jung might be available 'for a brief discussion' about the 'synchronistic processes' surrounding his mother's death. He repeated his request on November 5, 1960: 'It would mean a great deal to me if such a discussion were possible.' (IGPP Archive, E/21: Letter 5.11.1960 Bender to Jaffé in Correspondence with Jaffé 1957-1971) Jaffé had to put Bender off to a later date because Jung had gone on a long holiday to recuperate from health problems (IGPP Archive, E/21: Letter 10.11.1960 Jaffé to Bender). Jaffé was finally able to give Bender a positive answer on November 30, 1960, 'Professor Jung could see you on Thursday, December 8, at 11:30. Does this suit you?' (IGPPArchive, E/21: Letter 30.11.1960 Jaffé to Bender).

Hans Bender finally visited Carl Gustav Jung at his house in Küsnacht near Zürich on this date. Jung spoke with Bender about synchronistic phenomena for about $1 \frac{1}{2}$ hours. It was especially important to Bender to record this conversation; he had brought along his tape recorder from Freiburg for this reason. Apparently, there were initially technical difficulties; the German electric plug did not fit into the Swiss socket. Bender, however, was persistent, and the problem was eventually solved (Gruber 1993: 213-214). The tape with the original recording of the discussion between Bender and Jung now lies in the IGPP Archive (IGPP Archive, 4/2-370, E/20-215). 


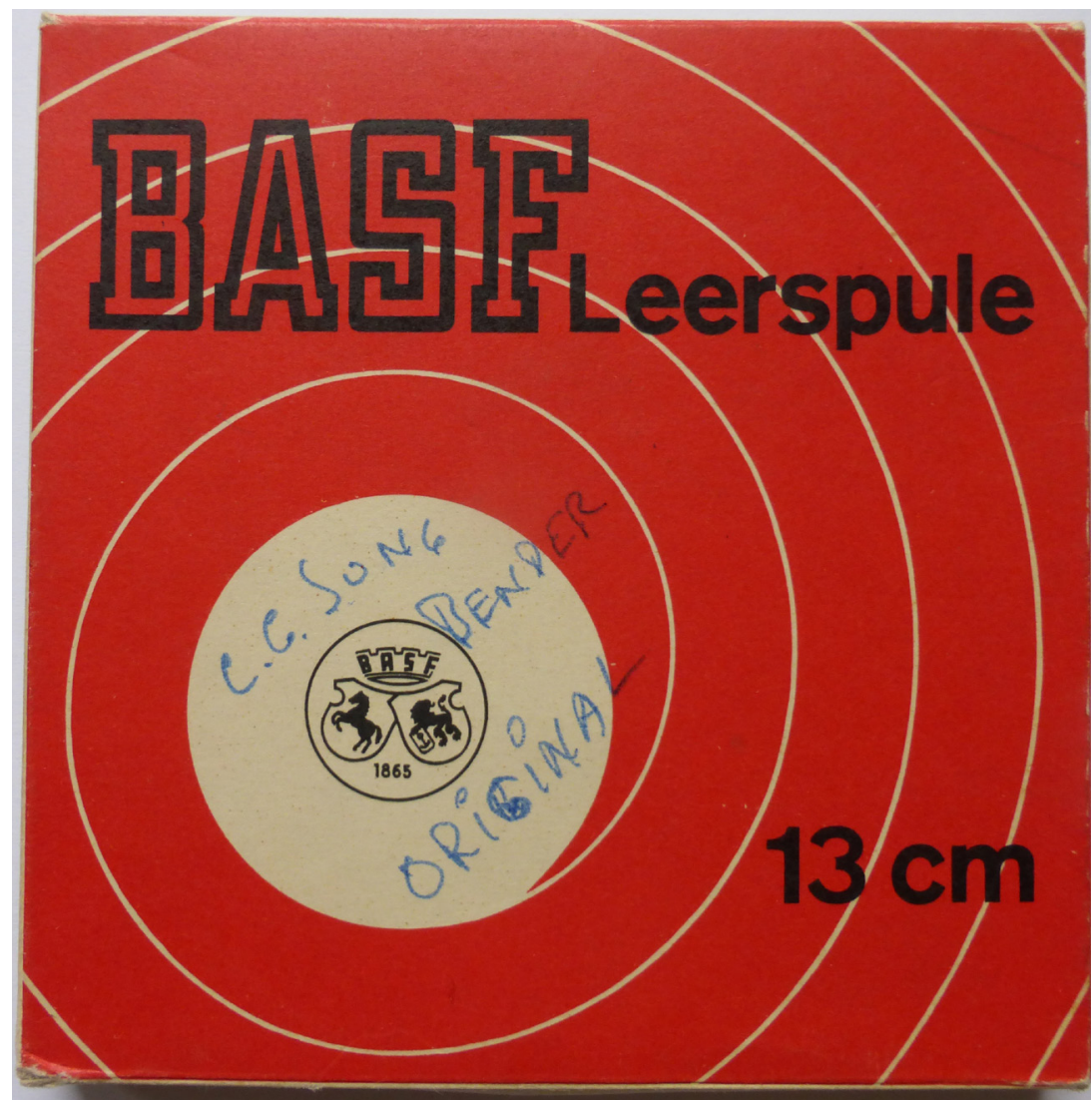

Fig. 4 Tape with the conversation between Bender and Jung (IGPP Archive)

\begin{tabular}{|c|c|c|c|c|c|}
\hline \multirow{2}{*}{$\begin{array}{c}370 \\
\text { Band-Nr. } \\
\text { Spur (Tempo) }\end{array}$} & \multicolumn{3}{|c|}{$\begin{array}{l}\text { Interview C.G.Jung } \\
\text { Gesamtthema }\end{array}$} & ZX Original u. Kopie & \multirow{2}{*}{$\begin{array}{r}13 \\
\phi \\
\text { Abschrift }\end{array}$} \\
\hline & Zähler & Ort/Datum & $\mathrm{Nr}$. & Inhalt & \\
\hline \multirow[t]{2}{*}{ I 4,5} & & 8.12 .1960 & 1 & Interview mit c.a. Jung duroh Bender & \\
\hline & n. $1 / 2$ & & & Frei & \\
\hline 11 & & & & Frei & \\
\hline & & & & & \\
\hline & & & & & \\
\hline & & & & & \\
\hline & & & & & \\
\hline & & & & & \\
\hline & & & & & \\
\hline & & & & & \\
\hline & & & & & \\
\hline & & & & & \\
\hline & & & & & \\
\hline
\end{tabular}

Fig. 5 File card for the recording (IGPP Archive) 
On June 6, 1961, about half a year after the conversation, Carl Jung died in Küsnacht. Aniela Jaffé personally informed Bender that Jung had 'died very peacefully in his sleep' (IGPP Archive, E/21: Letter 12.6.1961 Jaffé to Bender). Hans Bender again emphasised C. G. Jung's 'inestimable contribution' to parapsychology and edited his significant 'Letter on the Question of Synchronicity' to A. D. Cornell for the ZfP posthumously and in memory of Jung (Jung 1961).

C. G. Jung had a lively interest in questions of parapsychology up to the end of his scientific activity because he considered it to be the science "which is concerned with the biological and psychological events which show that the categories of matter, space, and time (and thereby causality) are not axiomatic'. Jung considered the greatest potential of parapsychological research to be in the 'examination and qualitative description of spontaneous events'. He reported this in a questionnaire on 'The Future of Parapsychology' for the International Journal of Parapsychology in July, 1960 (Jung 1993:545f).

\section{SUMMARY OF THE CONTENT OF THE CONVERSATION}

Bender started with a description of his car trip in the summer of 1960 from Freiburg via Zürich (August 19-20), Davos (August 20-21), Ascona (August 21-22), Pallanza on Lago Maggiore, Ventimiglia, and Nice (August 22) to Saint-Paul-de-Vence not far from the Côte d'Azur (see the table of events in the appendix). There he wanted to participate in a workshop of European parapsychologists organized by the Parapsychology Foundation in the Auberge Le Piol concerning further common activities. Hans Bender knew well the conference venue, 'Le Piol' in southern France, the European headquarters of the Parapsychology Foundation founded in 1951. He had participated in two consecutive international conferences with prominent speakers concerning 'Philosophy and Parapsychology' and 'Unorthodox Healings' in April, 1954 and had held a lecture himself on 'Methods of Paranormal Diagnosis' at the latter one (IGPP Archive, E/21-347; IGPP Archive, E/21-348; IGPP Archive, E/21-349; Alvarado, E. Coly, L. Coly \& Zingrone 2001:7-9; Parapsychology Foundation, Inc. 1957 and 1959). Bender desired, with the support of the Parapsychology Foundation, to host at the University Freiburg in Breisgau a large international convention on parapsychology and wanted to consult with his colleagues about this.

When he arrived at the Auberge Le Piol — due to an unplanned layover 
in Ascona-, only very late on the night of August 22 to 23, 1960, a telegram about his mother's sudden stroke in Freiburg on the same day (Monday, August 22) reached him. At the time of her stroke, at about noon, Bender was still in Ascona, listening to a lecture by the musicologist Victor Zuckerkandl.

After receiving the news of his mother's stroke, Bender wanted to book a return flight. This was not immediately possible and he delayed his departure. Therefore, Bender continued participating in the discussions about further cooperation among the parapsychologists present, and pursued his interests vehemently during the controversial discussions. ${ }^{6}$ Bender's mother, who had taken a car trip to Luzern and in the Albis mountain range two days before her stroke, died on the 24th of August 1960. At this point in time, Bender was still at the Auberge Le Piol near Saint-Paul-de-Vence.

He started the return trip on the afternoon of August 24, 1960, home via Geneva, where he had to spend the night, in an agitated mood on the afternoon of August 24, 1960. On the following day, August 25, in the small town of Coppet near Lake Geneva, Bender received the news by telephone of his mother's death, which had occurred on the previous day.

Bender told Jung how he had determined in retrospect, after his mother's death, that he had passed through a few places on the trip to Saint-Paul-de-Vence in which he, as a young man, had already been together with his mother: Zürich (1926), the Via Mala (1926), Ventimiglia, Nizza and Ėze (1929). He also mentioned the places along this way which had had a special meaning to his mother: Davos (her favourite ski resort) und Pallanza on Lago Maggiore (a stopover during her honeymoon in 1905). He further determined that he had passed by a place on his unplanned return trip that had been especially meaningful to him 35 years before, Coppet, which also housed Madame de Staël's grave. He had already been there at the age of 18 with a young woman from Zürich, to whom he felt very attracted in his first infatuation. ${ }^{7}$ Bender further told Jung about common experiences he had had with his mother,

6 See Anonymous (1969). Bender met up with Eileen J. Garrett, the President of the Parapsychology Foundation, the Italians Emilio Servadio and Roberto Cavanna, and the Frenchmen Alain Assailly and Hubert Larcher in Saint-Paul-de-Vence. Especially on August 23, 1960, they exhaustively discussed the organization and the contents of the planned conference in Freiburg in Breisgau, which was to be the subsequent event of the groundbreaking conference of the Parapsychology Foundation in Utrecht in 1953. The initially planned conference for the summer of 1961 was put off until the summer of 1962 and never came to pass because the Parapsychology Foundation finally pulled out.

${ }^{7}$ According to the information given by Hans Bender's daughter Janne Bender (3.3.2020) this girlfriend was Alma Ziegler from Zürich, who later married the artist and entrepreneur Kurt Schöpp and lived in Freudenstadt in the Black Forrest. 
as well as his remarkable emotional states during Zuckerkandl's lecture in Ascona and during earlier stopovers in Coppet and on the Albis (1925).

Jung, who listened to Bender's stories, attempted to analyse their synchronistic connections. He emphasized Bender's apparently especially emotional relationship with his mother (participation mystique) as a foundation of the synchronistic phenomena.

Bender had prepared himself very well for the conversation with Jung and supported his accounts with photographs and documents he had brought with him. The essence of the further conversation was, when reviewing the death of Bender's mother and the associated coincidences, the question to what degree a special archetype (like death and disease experiences) must always be 'constellated' in synchronistic experiences. That was Jung's fundamental assumption, whether non-determined, non-causal synchronicities could exist, or in Bender's words, 'synchronistic bagatelles'.

To pursue this question further, Bender mentioned his cooperation with the actress Christine Mylius (1913-1982). Mylius, who came from Munich and was intermittently engaged by the Freiburg theatre, had regularly written down recollections of her dreams since 1954 and had sent these texts to the IGPP for analysis of possible parapsychologically relevant contents. Over 3000 dream reports accumulated during almost 30 years, until Mylius' death. A large number of these were examined by IGPP colleagues for their precognitive contents (Bender 1974, Schriever 1988, Weber 2015). At the time when Bender visited Jung, this 'experiment with the future' had been going on for some time; over 1000 dream reports were available. During the weeks preceding the arranged appointment with Jung, Bender had worked up a preliminary, very detailed and meticulous analysis of Mylius' dreams together with his colleague, Johannes Mischo. They concentrated on a series of 12 striking dreams between 1954 and 1959, which were related to the actress' role in a film 'Night fell over Gotenhafen' (Nacht fiel über Gotenhafen) in which the authors thought they recognised attestable coincidences and resulting precognitive relationships (Bender and Mischo 1960/61, Bender and Mischo 1961). The film, which was produced and then shown in 1959, was about the dramatic sinking of the transport ship Wilhelm Gustloff filled with war refugees before the Pomeranian coast on January 30, 1945 (Tacke and Tuch 2010). ${ }^{8}$ Mylius' dreams also referred to scenes from

${ }^{8}$ For basic information about the film, see: https://www.imdb.com/title/tt0053092 [Accessed 25.3.2020]. When the Wilhelm Gustloff sank after being hit by a Soviet submarine, over 9000 passengers died. In addition to available scientific literature, Günther Grass, who was awarded a Nobel Prize for Literature, described this catastrophe in his novel 'Crabwalk' (Im Krebsgang) in 2002. See Schuch (1995) and 
the comedy, 'Triplets on Board' (Drillinge an Bord) with the famous German comedian Heinz Erhardt, which was produced at the same time as 'Night fell over Gotenhafen' and in the same film studio in Göttingen. Based on the remarkable examples from the 'Gotenhafen case', which later became very well-known in parapsychology circles (Bender 1966), Bender discussed the relativity of time perception and the "timelessness of the unconscious'. The parapsychologist from Freiburg had also brought Jung an urgent question, which he had formulated shortly before his study of Mylius' dreams, 'The problem which arises here will continue to be discussed; one can ask whether such relationships [meaning the correlations between the dreams and later events, remark by the authors] for a "capacity for extrasensory perception"- precognitioncan be claimed or if it could be better described by Jung's concept. This concept refers to the exceptionality of the event itself, the causally independent, meaningfully coincidental ("synchronistic") processes, for which time proves to be relative' (Bender and Mischo 1960/1961).

Therefore, Bender and Jung discussed the character of synchronistic phenomena and, above all, the meaning or also the neglect of the concept of archetypes. Jung again stressed that there really could be a 'meaningless synchronicity' in which archetypes do not play a role, but unexplainable things can occur due to a so-called excess of affect (excessus affectus); 'Then there is a miracle', Jung told Bender about the unique case of a young female patient whom he had healed without a method, but only through an intuitive idea - he had suddenly heard his dead mother singing - and healed the patient's massive sleep disturbance with a simple relaxation exercise. All doctors' efforts had previously failed. Jung had found himself in a peculiar, unexpected, 'compassionate' state with her, which achieved this assumed 'wonder'.

Then Bender and Jung began talking about the use of the Chinese book of wisdom I Ching, with which Jung had first experimented in the 1920s and whose practice as a 'mantic method' fascinated him for the rest of his life (Jung 1950, Jaffé 1960: 17-19). The I Ching ('Book of Transformations'), which is dated back to the third millennium B.C., was widely disseminated in the Western world thanks to the translation in 1924 by the theologian and sinologist, Richard Wilhelm (Wilhelm 1924). Bender also reported that he had always been highly impressed by the results of the Chinese oracle. Jung advised him to apply I Ching carefully and sparingly.

Before the conversation in Küsnacht abruptly came to an end, Bender

Niven (2011) for a history of the event and recollections of it. 
took advantage of the opportunity and tried to motivate Jung to contribute an article to a volume he was planning to publish on dream research. He further told Jung how interested his students in Freiburg were in Jungian analytical psychology. C. G. Jung appeared to be surprised by so much admiration.

In the documented conversation between Bender and Jung on December 8, 1960, an exceptionally graphic description of synchronicity develops, and in this setting, considerations about how the timeless realm of the unconscious (in the theory) can coincide with the time-related daytime consciousness and construct synchronistic events, which cannot be causally explained. Precognition, or at least 'presentiment', relate to future events in the examples cited in the conversation, like Bender's 'emotional mood in Coppet' 35 years before he received news of his mother's death, when he had been there at the age of 18 with a young woman from Zürich. Events are absolutely broken up into past, present, and future for a person's conscious experience. Future events haven't occurred yet; they cannot be experienced because they do not exist. During dreaming or in extraordinary states of consciousness, when a precognition or a 'presentiment' arises from the unconscious, it becomes apparent that 'the future [is] already present'. What we render as absolute past, present, and future in a normal state of consciousness collapses into a timeless archetypical world (Jung 1969). That makes it possible for an event that will only occur decades in the future to be felt now, in the present.

Institute for Frontier Areas of Psychology and Mental Health, Freiburg schellinger@igpp.de,anton@igpp.de,wittmann@igpp.de

\section{CONVERSATION BETWEEN HANS BENDER AND CARL GUSTAV JUNG ON DECEMBER 8, 1960}

B Professor Jung, may I quickly tell you about the events surrounding my mother's death?

J Yes, please do.

B My mother ${ }^{10}$ was an unusually vital woman, aged, very active; no one

9 The IGPP tape archive is the basis for the transcript: 40/2-370.

${ }^{10}$ Alice Bender, nee Hartlaub (1871-1960). 
expected her death. On a Friday I....

J She wasn't ill?

B She was not ill, not at all.

J Aha.

B Full of life. I took leave from her on a Friday evening. On August 18 or 19 , to spend a vacation in Davos with my wife ${ }^{11}$ and little daughter, ${ }^{12}$ and I had already planned to drive on to Ascona from Davos on Sunday, to spend the night there, and then, on the next day, Monday the $22^{\text {nd }}$, to drive to Nice. There was a conference there on parapsychology with my Italian colleague Servadio ${ }^{13}$ in an Auberge le Piol, ${ }^{14}$ which is located outside of Saint-Paul-de-Vence and belongs to Mrs. Garrett, ${ }^{15}$ the President of the Parapsychology Foundation. ${ }^{16}$ Well, I arrived in this Auberge late Monday and found a telegram, 'Mother stroke, come back immediately'. Now the following happened before that: looking back, I remembered that during this trip I had touched on all the places where I had been abroad with my mother. First place - or the ones connected with her. First place: Zürich. I spent the night from Friday to Saturday with my wife in Zürich. ${ }^{17}$ The following happened there many years ago. I met my wife in Bonn in 1931 or 1932, took a picture of her, as a young girl, and met up with my mother three weeks later in Zürich, showed her the photo, and said, 'This is my girlfriend.' My mother became very pensive and said, 'She looks just like a previous friend of mine, Fritz W., ${ }^{18}$ whom I actually nearly married'. Thereupon

\footnotetext{
${ }^{11}$ Henriette Bender, nee Wichert (1910-1979).

12 This is the daughter Janne Bender.

${ }^{13}$ Emilio Servadio (1904-1995): Italian psychoanalyst und parapsychologist, founder of the Psychoanalytic (1932) and the Parapsychological Society of Italy (1937/1955).

${ }^{14}$ Auberge Le Piol: near Saint-Paul-de-Vence in Southern France. The International Metaphysical Institute (Institut Métapsychique International) was founded here in 1954. The Parapsychological Foundation, founded in 1951, moved its European headquarters here in 1957.

${ }^{15}$ Eileen J. Garrett (1893-1970): Irish parapsychologist and medium in spiritualistic sittings.

${ }^{16}$ Parapsychological Foundation: founded by Eileen J. Garrett und Frances Payne Bolton in 1951.

${ }^{17}$ According to the recollection of Janne Bender (3.3.2020), they stayed overnight in Zurich at the home of Alma Ziegler's parents, the former girlfriend of Hans Bender.

${ }^{18}$ Fritz Wichert (1878-1951): art historian, Director of the Kunsthalle in Mannheim since 1909; Director of the Städelschule in Frankfurt a. M. since 1923; Henriette Wichert's father.
} 
I had to say, 'That is his daughter'. I had never heard about that from my mother.

J You see.

B That's the first. And then I drove to Davos, where my mother always went for sports. Then I drove over the little Sankt Bernhard, through the Via Mala, where I was with my mother in 1926, to Ascona. I arrived in the evening, spent the night. In Ascona I participated in an Eranos conference for the first and only time nine years ago and listened to your lecture about synchronicity. ${ }^{19}$ That was extraordinarily meaningful for me. I had to be in Nice the same evening and had little time, there was an Eranos conference. I decided to take a quick look and perhaps meet Mr. Portmann. ${ }^{20} \mathrm{Mr}$. Zuckerkandl was giving a lecture on the tonal figure (Tongestalt). ${ }^{21}$ That completely intrigued me. I remained seated; he demonstrated a thesis on a theme from a fugue from the Well-Tempered Clavier on the piano. And at that moment, I remembered I had studied it together with my mother, who was a pianist. The entire time came back to me. I was peculiarly moved and thought, 'Is the lecturer giving me back my lost relationship to music?' How very strange that all is! How good, I thought, that that will be printed in the Eranos Yearbooks; then it will be a document in my library. In the meantime it had become 11:30, and I should have gone away long ago. I must interrupt: my mother left the house in Freiburg at 11:30 to go to the bank on a scorching hot day. Came back at 1:00, rang the bell, she didn't enter and lay completely unconscious, having fallen over backwards. Didn't regain consciousness, died on Wednesday. At about 11:30 Mr. Zuckerkandl said, 'I will now demonstrate another theme, one from an old folk song and tell you the text'. And as he named the text, I fell into a state which is referred to as pathologic emotion. The text is, 'There is a cutter, called death, has power from the highest God. Today he sharpens his knife; it already cuts better, soon he will make the incision, we must suffer, beware you fine little flower' ${ }^{22}$ I have ...I was in such a strange state that I baffled myself, but didn't relate it to my mother. That was not in my mind at all.

\footnotetext{
${ }^{19}$ This Eranos conference took place from August 20 to 30, 1951. Jung's lecture 'Concerning Synchronicity' can be found in the Eranos Yearbook 10, 1951 (Jung, 1952a).

${ }^{20}$ Adolf Portmann (1897-1982): Professor of Zoology at the University of Basel since 1931 and Honorary Senator of the Albert-Ludwig University in Freiburg. Portmann was a lecturer at the Eranos conference in 1951, which Hans Bender attended.

${ }^{21}$ Victor Zuckerkandl (1896-1965): Austrian music historian of Jewish origin. After fleeing Vienna from the National Socialists in 1938, he taught music history at various universities in the USA. Between 1960 and 1964 he gave several lectures at Eranos conferences in Ascona.

${ }^{22}$ German folksong from the 17 th century; the author is unknown.
} 
J Yes, yes...

B Drove away at a quarter past twelve, past Lago Maggiore. And in Pallanza I suddenly had the feeling, 'This concerns my mother, but what is going on?' And after the burial, I was browsing through an old album of trips - it was a leg of her honeymoon trip.

\section{J Ah.}

B Then I drove through Italy and arrived in Ventimiglia late in the evening and drove along the Corniche to Nice. There I remembered, I was here with my mother in 1929, as her driver. And here....and then I came past a sign, Ėze, and thought, 'We were here, I took a photo here of an old farmwoman on a mule'. Suddenly the name occurred to me, Madame Carla. And then I thought, 'How long ago was that? How old can the woman be now? Died long ago'. I kept thinking about transience. After my mother's burial, I found the picture that I thought had been lost long ago, among correspondence on her working table.

J No!

B I had no idea. Here it is. It was coloured by an unknown hand. It was also in her immediate vicinity. Then I went to Le Piol. I received the news there: stroke. There was no airplane available. I waited. Waited too long and got away only on Wednesday morning because I then drove. At the moment of her death, on Wednesday at 11:20, I was still sitting, waiting for a telephone call-I only knew: stroke - on the terrace and looked at Saint-Paul-de-Vence. At that moment she died in Freiburg. No person was there. The entire family was away. Now, after the burial I looked for the notes of the Wohltemperierte Klavier to play the fugue. In front of me on top lay a book of notes, old. I opened it; it came from notes that I had once bought en bloc, that I had lost. It wasn't my mother's book of notes. I opened it. That was an old piano compendium of an opera by Rossini, $L a$ Donna del Lago. And inside there was a whole pile of postcards from Saint-Paulde-Vence. I photographed it here. [J: Oh!] From Saint-Paul-de-Vence, which I was looking at the moment she died. And on top is the picture album, where she pasted her honeymoon. [J: Yes] So she lived between these two photos, didn't she? Saint-Paul-de-Vence. And then I drove via Geneva, had to spend another night with my fear. Will I still see her alive, won't I see her alive? And from Geneva ... I was also afraid to phone. And from Geneva I was constantly looking for a post office along the way to be able to quickly phone and passed Coppet. ${ }^{23}$ And then I remembered very vividly that I had already had this condition of

${ }^{23}$ Coppet: a community in the Swiss canton Waadt on Lake Geneva, located about half an hour by car from Geneva today. 
inexplicable emotion twice. Namely as an 18-year-old, 1925, in Coppet. I had shortly before met a girl, a Swiss girl from Zurich, and that was my first very strong emotional relationship..$^{24}$ I was in the Coppet palace with her and saw the graveyard. And in front of the grave of Madame de Staë $2^{25}$ I had this emotional feeling, namely over the inscription 'Pourquoi cherchez-vous parmi les morts, celui qui sont vivants?' ${ }^{26}$ That moved me so deeply that I made up a poem about it, which I found again. It was 'Aus dem grünen Moose [?], Fremde Zeichen fast entschwunden, warum sucht ihr unter Toten, die da lebend euch verbunden?' (From the green moss [?]. Strange symbols, nearly vanished, why are you seeking her among the dead, she who united you while alive?). No, no, naturally a poem of a very young man. Coppet. And about 20 minutes later I telephoned and found out that she had died. And so it continued; those were essentially my experiences. Later I found out the following: that the two women who are woven into this, namely my wife and this girl from Zurich, that my mother took a picture of each together with me at exactly the place where she died. Now what happened to her? She drove on Sunday, when I was still in Davos - she was on the Executive Committee of the Richard-Wagner Association and had built up the association - she drove with the association in a private car which a colleague and admirer of my mother, a printer, Mr. Hahn, drove to Tribschen to visit the Richard-Wagner Museum. And from Tribschen she drove on a wonderful day, when she could suddenly see again; she had been operated for a cataract. ${ }^{27}$ She was fulfilled with the beauty, drove to Zurich on the Albis and saw the Alps again, the lake, and then drove, telling about her life, via Höchenschwand back to Freiburg. She arrived late in the evening, told her maid about the day's beauty into the night. And on the next day, she went to the bank, also in connection with this trip. She had namely wanted to get money from the bank on Saturday, but it was closed; she took it out of the association's cash box. And as a very correct woman, she wanted to put it back immediately on Monday. That's why she went to the bank. And now the following: this man who had driven her told me three and a half years ago, on February 7, 1957, after I had held a lecture at the RichardWagner Association about parapsychology, he had just had a very strange dream.

\footnotetext{
${ }^{24}$ This girlfriend was Alma Ziegler.

${ }^{25}$ Madame de Staël: Anne-Louise-Germaine, Baroness von Staël-Holstein (17661817): French intellectual and author.

${ }^{26}$ It should read: 'Pourquoi cherchez-vous parmi les morts celui qui est vivant dans le ciel?' Translation: 'Why are you looking for those who live in heaven among the dead?' (Luke 24.5)

27 Janne Bender emphasizes (3.3.2020) that this was an extraordinarily dangerous eye operation regarding a glaucoma. She suspects that Hans Bender therefore went on his journey to Davos and further to the South of France with some concern about the health condition of his mother.
} 
He said he otherwise never dreamed or didn't remember. He dreamed he was with my mother and other members of the Richard-Wagner Association on a trip, had returned in a happy mood with many conversations. Suddenly my mother floated away, looked around, smiling, one last time and disappeared. ${ }^{28}$ And I told him, 'Don't tell my mother this dream; it is a dream of death'. And explained one can have such a dream out of fear of losing someone. It was a true dream because it happened just that way. And there is something else...

J When did he have this dream?

B 1957. Three and a half years before her death. And I forgot it, although it was written down.

J Yes, yes.

B If I hadn't forgotten, I wouldn't have prevented my mother from taking this trip with him, [J: Yes], but I would have been alert and would have constantly thought about it. I have to add, my mother was a Grande Dame, whom no one was allowed to see when she wasn't completely in due form. She always said, 'I will go away with a "ping"'. And I couldn't stand to see her suffer. She ... the moment of her death is an instant when, what had never happened before, the entire close and distant family were all abroad. We all came too late. She took her leave when no one was there. And the last thing: she then drove on the Albis, and 35 years before, immediately thereafter, that was also exactly at the same time in the middle of August, I went from Coppet on the Albis with my girlfriend from Zurich. And then I had the same condition again, this emotion. And, I otherwise don't write poems, also made a poem about it. It's all so strangely interwoven.

J Yes, yes, yes.

B And now I would really like to know: what is your impression? Is it....

J Yes, it is a row of synchronic connections, isn't it? Which one cannot explain causally because that would, I don't know, into what speculations that would lead, right?

B Yes, yes.

J That is unthinkable. There are simply analogously convening factors. Precisely from the appropriate factors.

\footnotetext{
${ }^{28}$ At this point, 12 chimes rang, apparently from a wall or grandfather clock in the house. If the clock gives the correct time, the conversation began at 11:46.
} 
B You wouldn't make any differences? If you consider it parapsychologically, then you could say, this chauffeur's dream, the colleague's three years ago, was a precognitive dream.

J Yes.

B That was my supposition, my experience in Ascona would have been a presentiment, right?

J Yes.

B Perhaps it was, that may be a little audacious, the same feeling 35 years previously in Coppet, [was] also a presentiment?

J Yes.

B With which we can't do anything in parapsychology, is....

J Naturally, naturally.

B is that the picture in a book of notes of La Donna del Lago from a distance....

J Yes ...

B ... in the, was next to my mother. And the picture from Éze also next to her, right? We can't make anything of it.

$\mathrm{J} \quad$ Yes, exactly. But those are the crucial things, right? You probably have to see it this way: if you come to such a place which had already been touched by your mother, it is like if you came to a junction, right, of a longitude and a latitude, namely the prestabilised harmony. But since I cannot believe in the prestabilised harmony, I find no justification to assume that, moreover, the consequence would be that everything is only a machine. And we cannot assume that. Then it must be a so-called coincidence. But an analogous coincidence. An analogous merging. That is, on a certain place along your path you go parallel with your mother.

B Yes, yes.

J It's this way; at this place you come into your mother experience. [B: Yes] And then you are also the mother, as if you were the mother. So, and that is, of course, a regressive observation. Namely we then see, here is the child that is still in the mother. But since it is later, it is a participation mystique. Namely you hang spiritually or physically somewhere together with the mother experience. And 
whatever the mother lives or experiences, you experience it at the same moment. That is, at about the same moment.

B Yes, yes, yes.

$\mathrm{J} \quad$ Because you stand en participation mystique with her. What en participation mystique means, that is just difficult to explain. That is synchronicity, namely that is a connection which we cannot explain. For example, we are speaking here in this room about, let's say, a snake. And without our knowing it, a snake is creeping out there, exceptionally unusual, wouldn't happen. But if it were so, there is, unexpectedly, monstrously, there is a snake there. And that is as if the snake belongs in the pattern. We are talking about it, and it is there. Namely the snake, for God knows what reason, is in a participation mystique with us. That is coincidental.

B Yes, but you always tend to think about the meaning of such an experienced participation mystique. The meaning appears in evidence driven to the utmost in this synchronistic phenomenon. I have subjectively experienced, which has just become clear to me, that the bond to my mother was disproportionally greater than I had ever made myself aware.

J Precisely.

B And I have ...then her whole life became transparent to me. Suddenly I sought photographs everywhere. Here is, for example, the development of her face. I suddenly encountered her as a girl, right? And then I had it copied.

[Jung and Bender then look at the photographs that had been brought for several seconds, several pauses.]

J Yes, she is an exceptional personality. Without a doubt. Yes, one can well understand that you had a participation mystique with her.

B With Richard Strauss ${ }^{29}$ together, Julius Weismann. ${ }^{30}$ And then I found a picture where this participation mystique became rather clear. And the similarity. That is a picture that was taken at her place of death; that's me. She and I, isn't that so? And those are the pictures with her former friend's daughter, who became my wife, right?

J Now tell me, how did your mother behave towards your interests?

${ }^{29}$ Richard Strauss (1864-1949): famous German composer.

${ }^{30}$ Julius Weismann (1879-1950): composer born in Freiburg, named honorary citizen of Freiburg in 1939. 
B She had ... she was very interested in me. I was definitely her favorite son, I was her first child. But she was not the prototype of a tender mother. As a youth, when I was often very ill, although she ...very... I didn't let her [get close] to me, for the same reason because I didn't want to be suffering in her presence. I wanted to be fresh and strong. Then her sister, who was a Samaritan, always had to come to me. She [my mother] was not allowed, right? I...

$\mathrm{J} \quad$ Yes, but, I mean, was your mother interested in what you were interested?

B Yes, yes.

$\mathrm{J} \quad$ Was she interested in parapsychology?

B She always had me tell her about it, indeed.

$\mathrm{J} \quad$ Aha, aha. How was her marriage?

B It was an enduring, extremely difficult marriage.

J A difficult marriage?

B A very difficult marriage with a man whose lifestyle, no, with a completely opposite disposition. She was cheerful, optimistic with little depressive intervals. My father was a severe pessimist bordering on psychopathy who was upheld by her his whole life, but who, as a generous person, [provided] her with a very nice life-our house was full of artists, with car trips, and so forth, right? But it was a — and she undoubtedly had a....

$\mathrm{J}$ The question is, to what degree she, unsatisfied in the marriage, lived on through you.

B That was a marriage that was actually burned out, in any case in intimate relations, for many, many, many years.

J Yes, she apparently ... there is still an extra bond.

B Yes, yes.

$\mathrm{J}$ Not only the normal mother-son relationship, [B: Yes] but also a compensatory spiritual relationship with the son.

B That is quite certain. That is quite certain, and this... I also know what an influence that had on my personal history and my behaviour, but I really only know it.... 
J Yes, now it naturally comes to the surface when it is missing.

B I have only realized it since these experiences.

J Up to then, it was in her. Yes, and then you're not conscious of it. [B: Yes]. When she dies, then it comes in you, right, and only then can you become aware of it.

B Yes, yes.

J Well, I have the impression that your bond to your mother was a supernormal one. That is, an extra [B: Yes] strong bond.

B I would admit to that.

$\mathrm{J}$ And therefore, you see, there arise these phenomena of living with your mother-for you it's an experience to cross your mother's path, right? That means you also live a part of her life.

B Yes, yes, yes.

J That means, in other words, she continues living in you. The question is, she is now dead, how does that affect you? [B: Yes] I would assume that a benefit came back in your own life, [B: Yes] an expansion or intensification, something like that.

B That has actually already occurred.

J So? [B: Yes] Or, that is the return of libido, right, [B: Yes] but which is still affected by your mother, so that post-mortal phenomena which represent your mother are to be expected. And for some time to come. Until this return of libido is assimilated.

B What I expect is, how will this affect my relationship to my wife and then to women whom one meets?

$\mathrm{J}$ It is not only to women, but this is always also the mother world (Mutterwelt). [B: Yes] It is her spiritual horizon [B: Yes], for example. [B: Yes] It is this relationship with the mother world as a background to this world. [B: Yes] That is, a transcendental world. The roots. The mother. That, of course, is profound. Your mother will also include you partially in the sphere of the dead.

B Yes, it is to be determined that I only really realise for the first time: life has a temporal end, and what must one do to fulfil his task? The carpe diem in the sense of fertilisation. How much time is left? That was completely foreign to me.

J Yes, how far you have to fulfil yourself [B: Yes], right? And the danger is 
that the dead, even the best of them, when they die, they have an eerie effect, that is the primitive concept. And because one is drawn into the realm of the dead, part of your own life goes with her in death. And, of course, that causes huge repercussions. And [B: Yes] then there are all possible personal and objective repercussions.

B As I was thinking that over, the structure of these processes, it occurred to me to ask you. You say most reasonably: in the majority of cases, processes occur synchronically, then an archetype is constellated. [J: Yes] Now the synchronistic happened, beginning in Ascona, perhaps even earlier, at a time when I was not in such a condition. [J: Yes, yes, yes, yes]. Her death, I didn't suspect it.

J Apparently, right? Yes, that is only conscious, but your unconscious is not related to time in our sense. You are already in the atmosphere of death, right? [B: Yes] Whether 14 days earlier or later, that is, so to speak, the same. Because death is already present, isn't it? It is behind the next door, right? I have often experienced that people had a dream that anticipated a situation which only happened on the next day, right? [B: Yes] And they experienced the dream as if they had dreamed it later. If they had dreamed this after the situation, one would have said, 'Okay, of course they dreamed about it, it just happened yesterday.' But they actually dreamed of something and one doesn't understand at all why they dreamed it. And then the situation in the dream happens on the next day. [B: Yes, yes] But that must mean that the situation is already there.

B Is already there. [J: Yes] How would you interpret Schopenhauer's claim that this kind of dreams or precognitive dreams shows the determination of the individual?

J Yes, it is certainly true that the events, when they become obvious to us, such events [B: Yes] such archetypical events [B: Yes], like a death or a serious illness, that they have an enchainement, a causal enchaînement. So that you can say: because there was A, B must also exist, C must follow, and so on. Now, this gives us the impression as if fate were laid out. But we only observe individual cases, don't we? If it really were so, that everything that happens were ordered in this way, then I believe that such things would have to happen far more regularly. [B: Yes] They would have to be predictable [B: Yes]. Because a patient has a certain dream, and this dream announces an illness. Without a doubt: experience teaches us, I predict an illness which doesn't come about, it doesn't count, it is something else or nothing at all, right? It is an uncertainty relationship.

B Yes, may I repeat that again to check if I understood it correctly: you say that one certainly cannot infer a continuous determination from the admittedly rare and fragmentary character of precognitive experiences, synchronistic 
processes relating to the future?

J We see it in this case. We see an enchainement. But it is not certain that that is always so. We don't see all cases, do we? [B: Yes, yes] We only have cases in which we can see, for example, accidents. When I examine an accident, then I can be sure that I can find causality, a psychologic one. [B: Yes, yes] But I don't see all accidents; I cannot ensure that all accidents are caused by that. For example, take war, where thousands and thousands of thousands of people are killed. Is it always such an enchaînement, that the bullet hits him? Yes, we don't know, right? It isn't even probable. It is... certainly is the causation that is also a statistical truth [B: Yes], it is not an absolute truth. Because we cannot determine anything absolutely. And in our case, not even such a psychological connection is probable in all cases. But... indeed, one must say that synchronicity does exist, although there is no way in the world to discover a reason.

B Yes, there's something to that...

J That particularly interested me.

B The trifles, the synchronistic bagatelles. What's going on when you can't even find an affective background?

J You can't even say that there is some kind of archetypal constellation. And they are [B: Yes], they are dreamed in advance. I have dreamed utter nonsense, dreamed it in advance. And it literally happened. But that is, per se, nothing at all.

B Yes, right now I have such a case which we are working on and is so well documented that we are making a documentary film of it. An actress, who previously acted in the theatre in Freiburg, came in 1953 and said, 'I have dreamed since I was a girl and have repeatedly detected that some of these dreams actually materialise'. We made the following arrangement with her, 'Send us your dreams at short intervals. We will file them, and then send us confirmation when you believe that they have come true.' She did that faithfully with unheard of discipline. ${ }^{31}$ With the result that we have over a thousand dreams today. And now we see that a considerable number have come true. And that is especially evident in a group of 13 dreams. ${ }^{32}$ They began in 1954 and lasted until May 1959 and refer to details in a small role in a film, which she was first given in the summer of 1959. And we then determined that the film was only planned in March 1959. They [the dreams] refer to details in scenes which she played, in

${ }^{31}$ Christine Mylius (1913-1982): German theatre actress who played in several TV and cine films from the 1950s to the 1970s.

32 See: Bender \& Mischo (1960/1961) and Bender \& Mischo (1961). 
circumstances during the shooting, and to a second film which was shot at the same time, with some of the same scenery. The film in which she played was called 'Night Fell Over Gotenhafen' (Nacht fiel über Gotenhafen), a war film which shows the fate of a woman, for which she was partially to blame, in the horrible scene of the sinking of the Wilhelm Gustloff, which was torpedoed. ${ }^{33}$ Almost all of them drowned, ${ }^{34}$ and that is drastically shown in the film. And the other film is just the opposite; it is a comedian's slapstick film. ${ }^{35}$ And she dreamed individual scenes in advance, years in advance. And now I am making the strange observation that these probably precognitive dreams are not believed by the listeners because they say that they are so banal, it can't be true that it was dreamed in advance. May I present the structure of one such dream to you? She dreamed it on November 27, 1957. That is the original dream, which we filed. [Bender reads, partly from documents he brought with him] 'A ragingly funny comedian, he throws a wooden ball at someone's leg, she falls into the water, he goes with hat and clothes after her and fishes her out with his hat. He does that in December and without batting an eyelid. We were being very silly' ${ }^{36}$ And now a story with an actor wearing a dressing. She writes: 'One eye is blue, and then he removes the dressing, and a handsome man with long curls comes out'. ${ }^{37}$ That is the dream. And now it turns out that that in this film, which was shot at the same time in the same studio as the film in which she was, there was such a scene. In his enthusiasm for her playing, the comedian Erhardt ${ }^{38}$ throws a pianist ...

$\mathrm{J} \quad$ a vase $\ldots$

B A vase, a round vase [J: Yes] at her head, and he sings, 'I am a youth with curly hair.' And then everything goes overboard, falls into the water. ${ }^{39}$ A total fulfilment [of the dream].

J Yes.

${ }^{33}$ The cine film 'Night Fell over Gotenhafen' (Nacht fiel über Gotenhafen) about the sinking of the Wilhelm Gustloff on January 30, 1945, was directed by Frank Wisbar in 1959. The film was shown in German cinemas in 1960. See: Tacke \& Tuch (2010).

${ }^{34}$ See: Schuch (1995) and Niven (2011) for the history and memories of the sinking of the Wilhelm Gustloff.

${ }^{35}$ The comedy 'Triplets on Board' (Drillinge an Bord) with the popular actor Heinz Erhardt in 1959 is meant here.

${ }^{36}$ See: Bender \& Mischo (1960/61: 124). The 'Comedian Dream' (Komiker-Traum), November 27, 1957, is mentioned several times in the article.

${ }^{37}$ See: Bender \& Mischo (1960/61:125).

${ }^{38}$ Heinz Erhardt (1909-1979): a popular German comedian, actor, and entertainer in the post-war decades.

${ }^{39}$ See: Bender \& Mischo (1960/61:125). 
B And now, shortly thereafter, a year later, she has a very interesting dream. Referring to both films again. She writes: 'A very positive feeling upon waking, the dream teems with impressions and people that I cannot describe in words. It apparently deals with an expedition to Africa. Why, I don't know, because I see no Negros. And although it should be hot, we experience a snowstorm and landscapes that could be both, a snowy landscape and a sandy desert. The expedition is divided into two groups. ${ }^{40}$ Then she dreams, "There are deep catacombs resembling stage scenery, nightclubs, and other large rooms like those close to one another in film studios. Two slim and willowy dancers are dancing, rather lightly clothed, a kind of native dance. They must be twins. I think to myself, if both were as pretty as the Kessler sisters, ${ }^{41}$ they would certainly have an international career. But they have faces like bulldogs. Whole mood excited, adventurous, also with exertion, amusing, lots of to and fro, a huge number of people'. ${ }^{42}$ Now it turns out that she didn't understand the dream at all, she couldn't place it. It turns out that once the setting of the steamship Gustloff was erected outdoors at the film studio in Göttingen. Here the refugees boarded in a snowstorm, and directly next to it was a sandy desert with palm trees for Erhardt's slapstick film. No Negros, but an Arab expedition [J: Yes, yes] with donkeys. A nightclub was also erected in the studio for the Erhardt film, where lightly-dressed Creoles danced [J: Yes] —and also in the film studio, in the Gotenhafen film in which she played, the dance by two air-force assistants, in the film, they are called the Höpfner twins..$^{43}$ That is a pair, right, and they have... and now the question is, the general reaction to such dreams is this: to enlist synchronicity is a kind of sacrilege, such a banality that cannot be seen beforehand.

J Of course, of course, right? These dreams deserve utmost respect. They always interest me a lot, right? But I have always said that what one can understand from these dreams is the timelessness of the unconscious. The abnormal time which is connected to the unconscious. Indeed, a future content can possibly be present, is already present. The future is actually already present if time is relative. [B: Yes] Now I am convinced that time is relative. There is no absolute time; it is a phenomenon of consciousness. But the unconscious actually behaves as if it had no determined time. A dream can happen before or after. Entirely arbitrarily.

\footnotetext{
${ }^{40}$ See: the dream 'Climatic Paradox' (Klimatische Paradoxie), June 25, 1958, Bender \& Jung (1960/61:133). This dream is mentioned several times in the article.

${ }^{41}$ Alice and Ellen Kessler (born in 1936). The twins had great success in German show business, especially in the 1950s and 1960s.

${ }^{42}$ For the 'Atelier dream' on June 25, 1958, see: Bender \& Jung (1960/61:133). This dream is also often mentioned in the article.

43 The dancers and actresses, Hedi and Margot Höpfner (born in 1910), played in many cinema productions, especially in the 1930s.
} 
It is as if the unconscious were already there where we are not yet or is still there where we are no longer. That is also possible, but it is difficult to determine.

B In your article 'The Nature of Dreams' (Vom Wesen der Träume) ${ }^{44}$ [J: Yes] you made a comment that you have observed that patients' dreams are to be interpreted in relation to both their current and earlier situation [J: Yes], but that it later turned out, you have also...

$\mathrm{J} \quad$ in relation to the future...

B containing a synchronistic moment.

J Yes, naturally, yes, yes, yes, absolutely.

B Do you think ...

J Yes. Now look [B: Yes], when I am confronted with such a meaningless dream, I say to myself, apparently there are such phenomena in which the future is realised that can in no way be called synchronistic. [B: Yes] Because we see no possibility of a participation mystique. There is no corresponding archetype present, is there? [B: Yes] The situation is in no way archetypical [B: Yes] So why should the future suddenly become apparent? [B: Yes] Now I say to myself, there exist phenomena with an archetypical constellation, and this condition is indispensable for the appearance of this synchronicity. [B: Yes] On this basis we can understand why these two things come together. The snake is an archetype, if we are speaking of a snake and there is actually one outside, that can be explained by this psychology, right? If, however, such nonsense is simply perceived, that indicates that, aside from the archetypical explanation, we must also consider that time is relative and that we apparently sometimes see outside of the time slot, right?

B Yes, it is exceedingly important to me, Professor...

J Namely if one happens to look outside of the time slot, right? That is, of course, an entirely different explanation, it is a hypothesis. [B: Yes] But I'm not making schemata of it [B: Yes]. Indeed, if one does happen to look aside the time slot, I say to myself, these cases need to be observed separately.

B Need to be specially observed - now if it, for example, is possible, it is, I believe, almost easily possible to find the motivation here. It is a woman who has lived separated from her husband for a long time, but she is still very attached to him. And her husband has a new relationship with a very successful film star who is very famous. And she is modest, has an Ego-weakness; she doesn't assert

${ }^{44}$ Jung (1967). This article first appeared in the Ciba Zeitschrift in 1945. 
herself. She probably had the great desire to appear in a film [brief interruption in the recording] very rarely done. And besides, security-life protection-also plays a major role. That is the motivational network. And now we can determine that this reporter keeps a detailed diary of how these dreams were triggered; there are certain triggers. [J: Yes, yes] That is, triggers are, for example, two older men who pestered her, but from whom she [J: Yes] is professionally somewhat dependent, but whom she warded off. When she was with one or both of them in the evening, a precognitive dream steps into this film. We must examine how often this happens.

$\mathrm{J}$ In this case, it would have been intensive attention to the film and probably an excess of libido, which can cause the wrong viewpoint. [B: Yes] Because it is an excessus affectus, as Albertus Magnus says. [B: Yes] Isn't that right, an excessus affectus, that means it is like her relationship with her mother, which is even heightened by a contributing factor [B: Yes]. And that brings about such phenomena, which one cannot further explain archetypically when we have no archetype, none, or archetype-causing factor. [B: Yes] There could, however, be other contributing factors that are not induced by an archetype [B: Yes]. For example, this compensation, 'Don't look here, but over there'. And then there is here a ... [B: Yes ] or it can also be that one has a notion which is archetypical, and this results in a meaningless synchronicity, so to speak. Foresight, for example. I read a book and think about... while reading I suddenly have the lively notion of an eight-pointed star, a star-like figure. And then in the same book an essay about recent excavations appears, and a few pages further on, perhaps five minutes later, I find this star. A photograph, but it is of a wine press which was dug out, right? [B: Yes] But this little bit of foresight is probably caused by the archetype, provided the contributing factor, and this turns into excess, that is the excessus affectus. And then we have an abaissement du niveau mental, and then a wonder occurs. For example, if I foresee something in a patient's case or intuitively know the right means [to treat him/her]. I recently told my colleagues about such a case. There was a young girl who couldn't sleep, and her doctor sent her to me because he had reached the upper limit of any sleeping pill and didn't trust any further measures. He couldn't accept the responsibility. He wanted me to hypnotise or psychoanalyse her in an hour, right? And I saw that I could, of course, do that with the girl, a very nice girl, a grade-school teacher who tried terribly hard. And I took pity on her and said, for heaven's sake, she should, of course, relax, right? And I get her to relax, right, in an hour? And in a moment I was obsessed with this thought. 'What can I achieve with psychology? How could I help the girl?' And, I heard my mother's voice, my long-dead mother, how she sang a lullaby to my sister when she was a child, who had also died 
long ago. About a little girl sitting in a little boat with little fish in it floating down the Rhine. ${ }^{45}$ And then, without further reflection, I told her, 'Look, when sailing, you can wonderfully relax. Look, when you have the wind from behind and you set the spinnaker and gently sail up the sea, that's relaxation. Oh, it is already five o'clock; unfortunately, I can't do anything more for you. Adieu'. I never heard anything more from her. Four years later, at a congress, a little collega rusticus comes and drills me and says, 'Do you remember patient so and so?' I remembered. I said, 'Yes, how is she?' She went home and was healed.

B Very nice.

J She was healed. And what had happened? She never took any more sleeping pills. She had been on the summit of every narcotic. And he [her doctor] was desperate. And she went home and was healed. Lay in bed and slept like a child. And that has lasted since then. Then he [the doctor] said, 'Won't you be so kind, Professor, to explain what you did?' [Bender laughs] And I was, of course, terribly embarrassed; I naturally didn't know what to say. I couldn't tell him that I had sung a lullaby. I said, 'Yes, she had to relax, and I tried to teach her how to relax, and that was apparently successful'. [Bender laughs] And then he looked at me sadly. I saw that he was, in a sense, hurt. Namely because I had not told him the means with which one can relax someone within an hour.

B Which are probably the special circumstances which achieved it, because it probably doesn't always succeed?

J I was never able to use it again.

B What was so special?

J The special circumstance was that she was obviously in an emergency situation.

B Yes, but a shocking number of emergencies come to you.

J And I, by compassio connected with her, in an abaissement $d u$ niveau mental, an excessus affectus. [B: Yes] I didn't realise it at the time, and a wonder occurred. Namely, my mother sang. I heard her.

B Yes, but could one...

${ }^{45}$ We thank Matthias Güldenstein for pointing out to a popular Swiss-German nursery rhyme which could have been the one Jung referred to: 'Nina, Nina, 's fahrt es Meitschi der Rhyn ab. Was het es i sim Schiffeli? Gross und chlini Fischeli. Nina, Nina, 's fahrt es Meitschi der Rhyn ab.' In: Im Himmel lauft es Brünneli, Alti Värsli mit neue Bildli von Lotte Joost, A. Francke A.G. Verlag, Bern (1947). 
$\mathrm{J} \quad$ And that, right, I was affected [B: Yes], and she was affected. [B: Yes] And she was thereby healed.

B Indeed. But I mean that is probably no longer analysable, what is probably the exceptional case, that you came into this compassio? [J: Yes, of course] Is it a special kind of sympathy experience?

J You call it sympathy. In old medical terms it was sympathy. [B: Yes, yes]. That is the sympathetic cure. ${ }^{46}$

B A sympathetic cure. And this sympathy, although doctors want to give every patient sympathy, it does not arise in this passio a distante, that one is deeply moved.

J Usually a doctor exhibits, let's say, a certain medical benevolence, right, and so on. But I was moved by pity.

B Was there something particular, did you have...did she remind you of a...

J No, not at all, she was... I had the feeling she lives alone in a village, right? And is terribly isolated and she simply aroused my pity, right? And I thought, my God, she writhes in her sleeplessness; these drugs don't help any longer, and one should still help her, right? And that was an abaissement du niveau mental. I was moved by her sleeplessness. [B: Yes, yes] It hit me like an arrow.

B And thereby you performed a wonder.

J I was defeated. My defeat performed it. I said [to myself], 'How helpless we are after all, what can we do in such a case?' And my abaissement brought it about? And the abaissement permitted the automatism that my mother sang. And that was the magic ingredient.

B That is very impressive. But it just cannot be provoked, one...

J Yes, one can't; you can't experiment with it [B: Yes]. These stories are just unique, not repeatable [B: Yes] experiences.

B And that brings up a question that is very dear to my heart, I'll be finished with it soon. The temptation is very great to experiment with I Ching.

J You mustn't do that. That is a complete misunderstanding. I Ching, those

\footnotetext{
${ }^{46}$ Sympathetic cure: therapies based on non-conventional effects often ascribed to magic or the paranormal. Here, Frank Anton Mesmer's (1734-1815) tradition of 'animalistic magnetism'.
} 
are unique experiences.

B Yes, and I have a number of such experiences, where I, only in a really, genuinely questionable situation, threw the oracle and then received answers which were so harrowing. My question now entirely as a parapsychologist is this, from my experience with I Ching. Do you have the impression that the oracle reflects the momentary current emotional state of the inquirer, or does the oracle have a bearing on the objective situation, which may be fully hidden from the questioner?

$\mathrm{J} \quad$ Yes, right. Experience teaches us that the oracle is always compensatively focused on the questioner. [B: Yes] Even if you didn't ask a question, your situation will be answered. Sometimes you experience your situation only by means of I Ching. And that's why it's so illuminating. I always use it in dubious situations. And it's amazing how it works.

B I am deeply affected by it.

$\mathrm{J} \quad$ Yes, it is an entirely marvellous thing.

B And one can indeed allow oneself one thing, that you record this real question anyway and once- - then you get a picture.

J Yes, naturally, naturally. But only, that one...I always tell my colleagues, if they use I Ching, then with awe [B: Yes] and sparingly. [B: Yes] I have also tried to experiment; that didn't work out [in the original: das hat mir auf die Ohren gegeben].

[Someone knocks on the door.] $]^{47}$

J Yes, yes, come in.

B Professor, I would like to thank you very much and add a closing comment. I have with Mrs. Jaffét8 ... I told her that we prepared a small anthology from a dream colloquium at the Institute published by Franke. It contains a study about the formal analysis of dreams, a study about levels of recollection of a dream. A colleague, Miss Strauch, ${ }^{49}$ relates her dreams and those of test persons on a ${ }^{47}$ This is a funny coincidence. Right after Jung says: 'das hat mir auf die Ohren gegeben' (an unusal expression; literally in English: 'that has given me on the ears') someone knocks on the door.

${ }^{48}$ Aniela Jaffé (1903-1991): Swiss psychoanalyst and C.G. Jung's longtime colleague.

${ }^{49}$ Inge Strauch (1932-2017) was Hans Bender's assistant and interested in precognition in dreams, among other things. Strauch later became an important dream researcher in academia, initially as professor at the Saarland University and as professor at the 
tape when she wakes up at night. On the next morning, she writes them down as usual. Both versions are compared and show that the written texts already have strong variations. [J: Yes, yes] They are from the secondary processing [J: Yes, yes]. Another study - I am performing a study about the telepathic dream based on examples. And a different colleague working on the prospective dream where he goes from the understandable, normal prospective to the threshold of synchronicity. And now the big question whether you could ever contribute a few pages to this book. On the topic, 'What do you expect, what do I expect from future dream research? Where are ways that lead us further?'

$\mathrm{J} \quad$ If I only knew. That is a difficult question...

B Or this topic, that you just developed, 'Anticipatory dreams'. Then the problem that an archetype does not always have a constellation when such strange dream phenomena ... [J: Yes], that is, one expects an explanation. You just indicated that when you very carefully say an archetypical condition exists in most cases. [J: Yes] And now to mention a few examples of cases in which there is no archetypical condition [J: Yes, yes]. One could almost ...

J That again is difficult, isn't it? I have only one good example [B: Yes] where I believe I have to exclude any contribution of an archetype. But you see, the conception of this star, that is naturally a symbol used inflationary. [B: Yes] And it is, of course, full of archaisms. [B: Yes, yes] You can't derive anything from that. It must be such things like the duplicity of cases [B: Yes], for example. I read, for instance, a word on a day that I ...that is for the first time that I see it. And then I read the Zürcher Zeitung on the same day, and the word is also in the newspaper.

B That is so strange because one naturally has an inclination, when something miraculous, unfamiliar happens, that it reveals something special.

J It is just a grouping of coincidences, isn't it? The coincidences must agglomerate in groups, so to speak. And then, of course, there are phenomena which are just like synchronistic phenomena, but aren't; they are simply numerical coincidences. If that weren't so, it would be just routine [B: Yes], and then it wouldn't be an agglomeration. If it really is irrational and coincidental, then there are probably clusters.

B A question that popped up yesterday, that a colleague asked me, whether synchronistic phenomena are attached to people without their noticing it? University of Zürich from 1976 to her retirement as emeritus in 1999. Inge Strauch was a member of the Board of Directors of the Institute for Frontier Areas of Psychology and Mental Health (Institute für Grenzgebiete der Psychologie und Psychohygiene e.V. [IGPP]) until 2015. 
J Yes, yes. Of course, that exists.

B That someone else must come and say, 'Don't you see that everything is synchronistically tuned?'

$\mathrm{J} \quad$ Yes, that is very often the case that the people, for example, have a precognitive dream and just don't consider it important [B: Yes, yes] or give an account of it. Or they say to themselves, 'Oh, how strange.' and then forget it.

B Yes, thank you very much, Professor Jung.

J Yes, that was very interesting. These experiences ... [unintelligible].

B And may I also tell you that the Freiburg students are very eager readers of your books.

J Really?

B Yes. I hold a lecture with my modest means for students from all faculties about C.G. Jung's analytic psychology.

J Really? Aha, aha.

B And it sounds so boastful, but it is your name, not my name, there are always about 300-400 students.

J No!

B Yes. And they don't stay the whole time, but long enough.

J That is most interesting. Then, excuse me when I now say good-bye. I must.

B Many thanks! Many thanks!

J My lady is getting impatient.

B May I then...

J I'll leave you here...

B Yes.

J Good. 


\section{ARCHIVE DOCUMENTS}

Archive of the Institute for Frontier Areas of Psychology and Mental Health (IGPP) (Archiv des Instituts für Grenzgebiete der Psychologie und Psychohygiene e.V.)

$4 / 2-370$

$10 / 5-23$

$\mathrm{E} / 20-215$

E/21: Correspondence with Aniela Jaffé (1957-1971)

E/21: Correspondence with Carl Gustav Jung (1958-1961)

$\mathrm{E} / 21-311$

$\mathrm{E} / 21-312$

$\mathrm{E} / 21-347$

$\mathrm{E} / 21-348$

$\mathrm{E} / 21-349$

$\mathrm{E} / 23-1100$

Archives of the French Occupation in Germany and Austria (Archives de l'occupation française en Allemagne et en Autriche), Colmar

Bade 4103: Bender, Hans.

ETH library Zürich, University Archives (ETHZ, UA)

Hs 1056

\section{REFERENCES}

Alvarado, Carlos; Eileen Coly; Lisette Coly and Nancy Zingrone. 2001. 'Fifty Years of Supporting Parapsychology: The Parapsychology Foundation (1951-2001).' International Journal of Parapsychology 12:1-26.

Anonymous. 1969. 'European Researchers Meetfor RegionalConsultation.' Newsletter of the Parapsychology Foundation, Inc. 7(5):1.

Atmanspacher, Harald and Hartmut Römer and Harald Walach. 2002. 'Weak Quantum Theory: Complementarity and Entanglement in Physics and Beyond.' Foundations of Physics 32:379-406.

Atmanspacher, Harald and Christopher Fuchs (eds). 2014. The Pauli-Jung

Dialogue and its Impact Today. Exeter: Imprint Academic. 
Balkin, Jack. 2013. The Laws of Change: I Ching and the Philosophy of Life. Cork: BookBaby.

Bauer, Eberhard. 1998. 'Hans Bender und die Gründung des „Instituts für Grenzgebiete der Psychologie und Psychohygiene“.' In Jürgen Jahnke, Jochen Fahrenberg, Reiner Stegie and Eberhard Bauer (eds). Psychologiegeschichte-Beziehungen zu Philosophie und Grenzgebieten. Munich \& Vienna: Profil:460-476.

2015. 'Bender, Hans.' In Uwe Wolfradt, Uwe Elfride BillmannMahecha and Armin Stock (eds). Deutschsprachige Psychologinnen und Psychologen 1933-1945. Wiesbaden: Springer:31-33.

2016. 'Internationalisierung und Professionalisierung parapsychologischer Forschung im 20. Jahrhundert am Beispiel von "Parapsychology Foundation" und "Parapsychological Association".' In Anna Lux and Sylvia Paletschek (eds). Okkultismus im Gehäuse. Institutionalisierungen der Parapsychologie im 20. Jahrhundert im internationalen Vergleich. Berlin-Boston: de Gruyter/ Oldenbourg:245-275.

Bender, Hans. 1957/58. 'Vorbemerkung zu dem Artikel "Ein astrologisches Experiment” von Carl Gustav Jung.' Zeitschrift für Parapsychologie und Grenzgebiete der Psychologie 1:81-92.

. (1959). 'Zur Psychologie der UFO-Phänomene.' Zeitschrift für Parapsychologie und Grenzgebiete der Psychologie 3:32-58.

. (1960). 'Editorial: C. G. Jung zum 85. Geburtstag.' Zeitschrift für Parapsychologie und Grenzgebiete der Psychologie 4(1):1-7.

. (1966). 'The Gotenhafen case of correspondence between dreams and future events: A study of motivation.' International Journal of Neuropsychiatry 2(5):398-407.

(ed). 1974. Christine Mylius: Traumjournal. Experiment mit der Zukunft. Stuttgart: DVA.

Bender, Hans and Johannes Mischo. 1960/1961. "Praekognition” in Traumserien. Dokumentation und Sinnanalyse sinnvoller Koinzidenzen im 'Fall Gotenhafen" [Teil 1].' Zeitschrift für Parapsychologie und Grenzgebiete der Psychologie 4(2)/3:114-198.

.1960/1961. "Praekognition" in Traumserien. Dokumentation und Sinnanalyse sinnvoller Koinzidenzen im 'Fall Gotenhafen” [Teil 2].' Zeitschrift für Parapsychologie und Grenzgebiete der Psychologie 5(1):10-47. 
1983. 'Hans Bender im Gespräch mit Johannes Mischo (1983).' In Eberhard Bauer and Walter von Lucadou (Ed). Spektrum der Parapsychologie. Hans Bender zum 75. Geburtstag. Freiburg: Aurum:15-25.

Gieser, Suzanne. 2005. The Innermost Kernel. Depth Psychology and Quantum Physics-Wolfgang Pauli's Dialogue with C. G. Jung. New York: Springer.

Gruber, Elmar. 1993. Suche im Grenzenlosen. Hans Bender-ein Leben für die Parapsychologie. Köln: Kiepenheuer \& Witsch.

Hausmann, Frank-Rutger. 2006. Hans Bender (1907-1991) und das 'Institut für Psychologie und klinische Psychologie' an der Reichsuniversität Straßburg 1941-1944. Würzburg: Ergon.

—. (2005/2006/2007). 'Hans Benders Bonner Assistenten- und Dozentenjahre.' Zeitschrift für Parapsychologie und Grenzgebiete der Psychologie 47/48/49:208-226.

- (2013). 'Wissenschaftslenkung an der Reichsuniversität Straßburg: Ernst Anrich, Hans Bender und das "Grenzwissenschaftliche Institut".' In Krimm, Konrad (ed). NS-Kulturpolitik und Gesellschaft am Oberrhein 1940-1945. Ostfildern: Thorbecke:131-143.

Jaffé, Aniela. 1960. 'C. G. Jung und die Parapsychologie.' Zeitschrift für Parapsychologie und Grenzgebiete der Psychologie 4:8-23.

Jung, C. G. 1902. Zur Psychologie und Pathologie occulter Phänomene. Eine psychiatrische Studie. Leipzig: Mutze.

Jung, C. G. (1950). Foreword. In: The I Ching or Book of Changes. The Richard Wilhelm translation, rendered into English by Cary F. Baynes, foreword by C. G. Jung. New York: Pantheon Books:i-xx.

—.1952a. 'Über Synchronizität.' In OlgaFröbe-Kapteyn(ed). EranosJahrbuch 1951, 20: Mensch und Zeit. Zürich: Rhein-Verlag:271-284.

. 1952b. 'Carl Gustav Jung: Synchronizität als ein Prinzip kausaler Zusammenhänge.' In Carl Alfred Meier (ed). Naturerklärung und Psyche. Zürich: Rascher:1-107.

. 1957/1958. 'Ein astrologisches Experiment.' Zeitschrift für Parapsychologie und Grenzgebiete der Psychologie 2/3:81-92.

(1958). Ein moderner Mythus. Von Dingen, die am Himmel gesehen werden. Zweite Auflage. Zürich and Stuttgart: Rascher Verlag. 
(1961). 'Ein Brief zur Frage der Synchronizität.' Zeitschrift für Parapsychologie und Grenzgebiete der Psychologie 5(1):1-9.

. (1967). 'Vom Wesen der Träume.' In Marianne Niehus-Jung, Lena Hurwitz-Eisner, Franz Rinklin, Lilly Jung-Merker and Elisabeth Rüf (eds). C. G. Jung: Die Dynamik des Unbewussten (Gesammelte Werke 8). Zürich \& Stuttgart: Rascher:321-338. (English version: Collected Works of C. G. Jung. vol. 8, §§530-569).

—. (1973). 'Briefe zur Parapsychologie II'. Zeitschrift für Parapsychologie und Grenzgebiete der Psychologie 3:139-170. (1979). Flying Saucers: A Modern Myth of Things Seen in the Skies. NJ: Princeton University Press.

(1993). Gesammelte Schriften XVIII/2: Das symbolische Leben. Verschiedene Schriften, 2nd edition (1st edition 1981). SolothurnDüsseldorf: Walter (English version: Collected Works of C. G. Jung. vol. 18).

Jung, C. G. \& Pauli, W. 1955. The Interpretation of Nature and the Psyche. London: Routledge \& Paul.

Kaltenbrunn, Dominik. 2015. Die Anfänge parapsychologischer Institutionalisierung in Deutschland: Hans Bender und Freiburg i. Br. Bachelor Thesis at the University Freiburg (IGPP Archive, 40/1-337).

Loewe, Michael. 1981. 'China.' In Michael Loewe and Carmen Blacker (eds). Divination and Oracles. London: Allen \& Unwin:39-62.

von Lucadou, Walter; Hartmut Römer and Harald Walach. 2007. 'Synchronistic Phenomena as Entanglement Correlations in Generalized Quantum Theory.' Journal of Consciousness Studies 14(4):50-74.

Lux, Anna. 2013. "“Vom spielenden Gelingen.” Hans Bender (1907-1991) und die öffentlichen Medien.' Historische Anthropologie 21(3):343366.

2015. 'On all Channels: Hans Bender, the Supernatural and the Mass Media'. In Monica Black and Eric Kurlander (eds). The Nazi Soul between Science and Religion: Revisiting the Occult Roots and Legacies of the Third Reich. Rochester, NY: Camden House:223-247.

Mayer, Gerhard. 2019. 'Editorial: Zum Kern der Sache_Carl Gustav Jung, Synchronizität und das Ringen mit empirischen Daten'. Zeitschrift für Anomalistik 19(3):284-299. 
Miller, Arthur. 2009. Deciphering the Cosmic Number. The Strange Relationship of Wolfgang Pauli and Carl Jung. New York: W. W. Norton.

Miller, Thomas. 2010. 'Bender, Hans' in Friedrich Wilhelm Bautz and Trugott Bautz (eds). Bio-bibliographisches Kirchenlexikon 31. Nordhausen: Verlag Traugott Bautz:82-89.

Moragiannis, Janne. 2003. 'Parapsychologie an der "Reichsuniversität Straßburg." Hans Bender und die grenzwissenschaftliche Abteilung am "Institut für Psychologie und Klinische Psychologie," 1941-1944'. Le Détour Europe. Revue des Sciences Humaines, NF 1:155-176.

Niven, Bill. 2011. (ed). Die Wilhelm Gustloff: Geschichte und Erinnerung eines Untergangs. Halle: Mitteldeutscher Verlag.

Parapsychology Foundation, Inc. 1957. (ed). Proceedings of Four Conferences of Parapsychological Studies. New York, N.Y.: Parapsychology Foundation, Inc.

- 1959. (ed). Report on Five Years of Activities. New York, N.Y.: Parapsychology Foundation, Inc.

Resch, Andreas. 1991. 'Hans Bender (1907-1991). Leben und Werk.' Grenzgebiete der Wissenschaft 40:99-120.

Roesler, Christian. 2014. 'A Research Frame for Investigating the Appearance of Synchronistic Events in Psychotherapy.' In Harald Atmanspacher and Christopher Fuchs (eds). The Pauli-Jung Dialogue and its Impact Today. Exeter: Imprint Academic.

_ 2018. 'Synchronistic Experiences in Psychotherapy: An Ongoing Study'. In Christian Roesler (ed). Research in Analytical Psychology. London: Routledge.

Roesler, Christian and Daniel Giebeler. 2015. 'Synchronizität: Sinnvolle Koinzidenzen'. In Gerhard Mayer, Michael Schetsche, Ina SchmiedKnittel and Dieter Vaitl (eds). An den Grenzen der Erkenntnis. Handbuch der Anomalistik. Stuttgart: Schattauer:243-255.

Schellinger, Uwe; Marc Wittmann, and Andreas Anton. 2019. '„Das ist alles so eigentümlich verschachtelt. Hans Bender und Carl Gustav Jung im Gespräch über Synchronizität (1960)'. Zeitschrift für Anomalistik 19:420-467.

Schriever, Friedericke. (1988). 'Ein 30jähriges Experiment mit der Zukunft. Evaluation einer Einzelfallstudie des Freiburger Instituts für 
Grenzgebiete der Psychologie und Psychohygiene.' Zeitschrift für Parapsychologie und Grenzgebiete der Psychologie 30,1/2/3/4:99-132.

Schuch, Hans. 1995. (ed). Flucht über die Ostsee 1944/45. Der Untergang der Wilhelm Gustloff vor 50 Jahren (Ausstellung vom 14. Januar bis 19. März 1995). Münster: Westpreußisches Landesmuseum.

Tacke, Alexandra and Geesa Tuch. 2010. 'Frauen auf der Flucht: "Nacht fiel über Gotenhafen" (1959), "Die Flucht" (2007) und die "Die Gustloff" (2008) im Vergleich.' In Elena Agazzi and Erhard Schütz (eds). Heimkehr - eine zentrale Kategorie der Nachkriegszeit: Geschichte, Literatur und Medien. Berlin: Duncker \& Humblot:229-242.

Weber, Anton. 2015. 'Die Traumtagebücher der Christine Mylius (19131982).' In Günther Klugermann, Anna Lux and Uwe Schellinger (eds). Okkultes Freiburg. Ereignisse-Personen-Schauplätze. Kassel: Herkules:58-60.

Wilhelm, Richard. 1924. I Ging. Das Buch der Wandlungen. Jena: Eugen Diederichs.

Yiassemides, Angeliki. 2014. Time and Timelessness. Temporality and the Theory of Carl Jung. Milton Park: Routledge. 
Appendix: Table of the Events Involving Hans Bender and his Mother Reported in the Conversation Between Hans Bender and C. G. Jung

\begin{tabular}{|c|c|c|c|}
\hline Day and Date & Hans Bender's Car Trip & $\begin{array}{l}\text { Events Before and Relating to the Death of } \\
\text { Bender's Mother }\end{array}$ & $\begin{array}{l}\text { Other Synchronistic Events in Time and } \\
\text { Space }\end{array}$ \\
\hline $\begin{array}{l}\text { Friday } \\
19.8 .1960\end{array}$ & $\begin{array}{l}\text { Drive from Freiburg to Zürich with } \\
\text { wife and little daughter. Overnight } \\
\text { stay at the home of Alma Ziegler's } \\
\text { parents. } \\
\text { (The trip's destination is a parapsychological }\end{array}$ & & $\begin{array}{l}\text { Bender met his future wife in Bonn in } 1932 \text { and } \\
\text { took a photograph. He meets up with his mother } \\
\text { in Zürich three weeks later and shows her the } \\
\text { photo. She recognizes the daughter's similarity } \\
\text { to her father, whom she (Bender's mother) } \\
\text { almost married. }\end{array}$ \\
\hline
\end{tabular}

(The trip's destination is a parapsychological conference with his Italian colleague Servadio in the Auberge Le Piol near Saint-Paul-de-Vence. The Auberge Le Parapsychological Foundation.)

$\begin{array}{ll}\text { Saturday } & \text { Drive from Zürich to Davos to take wife }\end{array}$
and daughter to a holiday destination.

20.8.1960

Drive from Davos over the Little St.

Sunday Bernhard Pass, through Viamala to Ascona, where he arrives in the evening.

Bender's mother, a member of the Board of Bender's mother was often in Davos for riding sports.

Ascona, where he arrives in the evening.
drives with Mr. Hahn, a printer and admirer, to Bender attended Tribschen to visit the Richard-Wagner Museum. in Ascona and heard Jung's lecture on Mrs. Bender had a cataract operation just synchronicity in 1951 ('nine years ago'). previously and can now see well. On the return trip, she and Hahn drive over the Albis. There she again sees the Alps and Lake Zürich. They then drive back to Freiburg via Höchenschwand Mr. Hahn tells Hans Bender about a nighttime dream on 7.2.1957, $31 / 2$ years before Bender's mother's death. In the dream, he is Bender's mother's death. In the dream, he is
travelling with his mother and other members of the Richard-Wagner Association. Suddenly the mother floats away in a happy mood and disappears. At that time Bender already interpreted the dream as a dream of death

late in the evening and tells the domestic work about her lovely day until late at night.

35 years previously, after Bender was in Coppet with his girlfriend from Zürich, Alma Ziegler where he felt an unexplainable emotion. He then drove with her on the Albis, where he again experienced the emotional condition. 


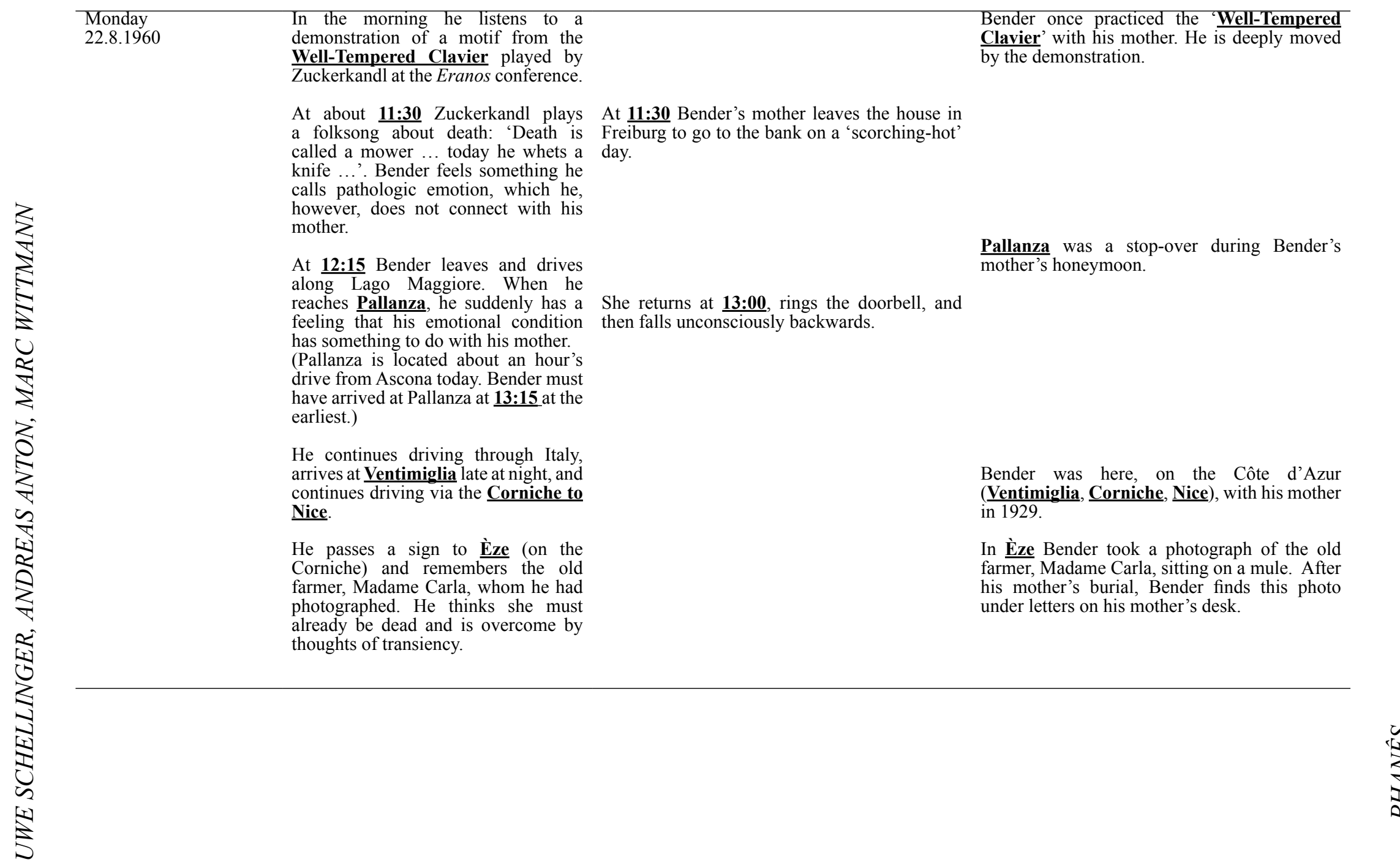


Bender drives on to the Auberge Le

Piol located outside of Saint-Paul-de-

Vence, where he receives the news of

his mother's stroke.

The telegram: 'Mother stroke come at

once.'

Tuesday

Bender tries in vain to get a return

flight to travel back to Freiburg as

quickly as possible.

\begin{tabular}{|c|c|c|}
\hline $\begin{array}{l}\text { Wednesday } \\
24.8 .1960\end{array}$ & $\begin{array}{l}\text { Bender is on the terrace of the Mother dies at } \underline{\mathbf{1 1 : 2 0}} \text {. } \\
\text { Auberge Le Piol at } \mathbf{1 1 . 2 0} \text { waiting for a } \\
\text { phone call and looking down at Saint- } \\
\text { Paul-de-Vence when his mother dies. } \\
\text { Drives to Geneva and spends the night } \\
\text { there. }\end{array}$ & $\begin{array}{l}\text { After his mother's burial, Bender searches } \\
\text { under the notes of the 'Well-Tempered Clavier' } \\
\text { and in the piano score of the Rossini opera 'The } \\
\text { Lady of the Lake' (La Donna del Lago) finds a } \\
\text { pile of postcards from Saint-Paul-de-Vence, on } \\
\text { which he was looking down when his mother } \\
\text { died. }\end{array}$ \\
\hline $\begin{array}{l}\text { Donnerstag } \\
25.8 .1960\end{array}$ & $\begin{array}{l}\text { Driving from Geneva, Bender seeks } \\
\text { a post office to make a telephone }\end{array}$ & $\begin{array}{l}\text { Hans Bender had already had an emotional } \\
\text { condition in Coppet. }\end{array}$ \\
\hline & $\begin{array}{l}\text { he will meet his mother while she is } \\
\text { still alive. He is also fearful of the } \\
\text { telephone call. Bender passes Coppet } \\
\text { (on Lake Geneva). } \\
\text { Twenty minutes after passing Coppet, } \\
\text { Bender hears about his mother's death } \\
\text { (he possibly found a post office and } \\
\text { called from there). }\end{array}$ & $\begin{array}{l}\text { Bender had his first strong emotional } \\
\text { relationship with his first girlfriend (Alma } \\
\text { Ziegler from Zürich) as an 18-year-old in } 1925 . \\
\text { Standing in front of Madame de Staël's grave } \\
\text { in Coppet, he reads the inscription, 'Why are } \\
\text { you looking for the living among the dead?' } \\
\text { (Pourquoi cherchez-vous parmi les morts, ceux } \\
\text { qui sont vivantes?). He is so moved that he } \\
\text { writes a poem about mortality. }\end{array}$ \\
\hline & & $\begin{array}{l}\text { Photographs exist with each of the two woman } \\
\text { with Bender on the very place where his } \\
\text { mother's stroke occurred, before the front door } \\
\text { (Bender calls it the 'death place') which remind } \\
\text { him emotionally of Coppet. }\end{array}$ \\
\hline
\end{tabular}

